IZA DP No. 8052

UN Interventions: The Role of Geography

Juan C. Duque

Michael Jetter

Santiago Sosa

March 2014 


\title{
UN Interventions: The Role of Geography
}

\author{
Juan C. Duque \\ RISE Group, Universidad EAFIT \\ Michael Jetter \\ Universidad EAFIT \\ and IZA \\ Santiago Sosa \\ Universidad EAFIT
}

Discussion Paper No. 8052

March 2014

\author{
IZA \\ P.O. Box 7240 \\ 53072 Bonn \\ Germany \\ Phone: +49-228-3894-0 \\ Fax: +49-228-3894-180 \\ E-mail: iza@iza.org
}

\begin{abstract}
Any opinions expressed here are those of the author(s) and not those of IZA. Research published in this series may include views on policy, but the institute itself takes no institutional policy positions. The IZA research network is committed to the IZA Guiding Principles of Research Integrity.

The Institute for the Study of Labor (IZA) in Bonn is a local and virtual international research center and a place of communication between science, politics and business. IZA is an independent nonprofit organization supported by Deutsche Post Foundation. The center is associated with the University of Bonn and offers a stimulating research environment through its international network, workshops and conferences, data service, project support, research visits and doctoral program. IZA engages in (i) original and internationally competitive research in all fields of labor economics, (ii) development of policy concepts, and (iii) dissemination of research results and concepts to the interested public.
\end{abstract}

IZA Discussion Papers often represent preliminary work and are circulated to encourage discussion. Citation of such a paper should account for its provisional character. A revised version may be available directly from the author. 


\section{ABSTRACT}

\section{UN Interventions: The Role of Geography*}

This paper argues that UN military interventions are geographically biased. For every 1,000 kilometers of distance from the three Western permanent UNSC members (France, UK, US), the probability of a UN military intervention decreases by 4 percent. We are able to rule out several alternative explanations for the distance finding, such as differences by continent, colonial origin, bilateral trade relationships, foreign aid flows, political regime forms, or the characteristics of the Cold War. We do not observe this geographical bias for non-military interventions and find evidence that practical considerations could be important factors for UNSC decisions to intervene militarily.

JEL Classification: D74, F52, F53, N40, R12

Keywords: United Nations, conflict resolution, international organizations

Corresponding author:

Michael Jetter

Department of Economics

School of Economics and Finance

Universidad EAFIT

Carrera 497 Sur-50, Avenida Las Vegas

Medellín

Colombia

E-mail:mjetter7@gmail.com

\footnotetext{
*We thank seminar participants at the NIW (Hannover, Germany), the Universidad de Los Andes, the Southern Methodist University, and the University of Memphis for their valuable comments and discussions. We are especially grateful to Pedro Amaral, David Bardey, Theodore Breton, Leopoldo Fergusson, Alan Finkelstein Shapiro, Andrew Hussey, Louis Jaeck, David Kemme, James Lake, Mark Mullenbach, Albert Okunade, Ömer Özak, Timothy C. Salmon, Fabio Sánchez, Hans-Peter Schmitz, William T. Smith, David Stadelmann, Stephan Thomsen, Hernán Vallejo, Andrés Zambrano, and Hernando Zuleta for helpful comments and discussions.
} 
The whole basis of the United Nations is the right of all nations - great or small - to have weight, to have a vote, to be attended to, to be a part of the twentieth century. Adlai E. Stevenson

\section{Introduction}

Why does the United Nations Security Council (UNSC) decide to intervene in some conflicts but not in others? For a long time, UN military interventions, and especially non-interventions, have been subject to criticism from the international community. For example, consider the hesitant UN actions surrounding the Rwandan genocide of 1994. Then Secretary General Kofi Annan later admitted that "the international community failed Rwanda." ${ }^{1}$ However, other contemporary conflicts, such as the Yugoslav wars, have received much greater attention from the UN. Would the treatment of Rwanda have been different if the country was located in Europe?

This paper tries to shed light on the factors associated with UN military interventions, particularly focusing on the geographical component in relation to the five permanent UNSC members (China, France, Russia, the UK, and the US). Previously, numerous observers criticized the predominant role of the five permanent UNSC members (e.g., Childers, 1994, or Rajan, 2006). In theory, the geographical proximity to these powers should not be related to the probability of UN interventions, because one of the main UN guidelines advocates its role of keeping peace throughout the world. The following pages suggest otherwise.

Recently, evidence for biased decisions in international organizations has become stronger. Thompson (2006) describes why powerful states may use major international organizations to pursue their interests. Oatley and Yackee (2004) conclude that the US may use its influence in the IMF for its own purposes. As for the United Nations, Dreher et al. (2009a) and Dreher et al. (2009b) show that non-permanent UNSC members tend to receive favorable treatment from the IMF and the World Bank. Kuziemko and Werker (2006) find that UN aid, but also US aid, increases when a country rotates onto the UNSC. Our paper adds to the literature on a potential bias in UNSC decisions by showing that interventions tend to occur in conflicts that are geographically closer to its three permanent Western members.

As for the existing literature on UN intervention determinants, Jakobsen (1996) discusses

\footnotetext{
${ }^{1}$ See BBC (2004) and Times (1994).
} 
potential drivers of five particular UN peace enforcement operations. Voeten (2001) provides a game-theoretic approach to explain voting in the UNSC. Stojek and Tir (2011) argue that the economic interests of the five permanent UNSC members play an important role in UN intervention decisions. Some literature has examined third-party interventions in general terms, finding the behavior of other potential intervening countries to matter (Aydin, 2010) along with ideological linkage and geographical proximity (Mullenbach, 2005). Perkins and Neumayer (2008) find that a country's decision to participate in peacekeeping operations can be influenced by its geographical proximity to the conflict nation. However, while geographical proximity may present a justifiable reason for intervention decisions by single countries (or countries participating in an intervention authorized by regional organizations), in theory it should not enter UNSC decisions.

Geographical proximity has been discussed as a determinant for foreign military intervention, both in general (Pearson, 1974, Perkins and Neumayer, 2008) and in the context of the US (Mullenbach and Matthews, 2008). Neack (1995) has hinted that states might participate in UN interventions predominantly for selfish reasons. In fact, selfish reasons for a UNSC member to push for a UN intervention close to home are easy to find. In addition to political and economic ties, the conflict may spread further (like the current conflict in Syria spilling over to Lebanon or the conflict in Kosovo threatening to spark violence in Albania), major immigration waves could result from nearby conflicts (e.g., North African immigration waves to Europe during the Arab Spring, especially to Italy), or it may simply be more expensive to intervene in conflicts located further away. Our findings indicate that neither political nor economic reasons can explain the importance of distance, but we do find some evidence that practical reasons could drive our results. It may simply be that the chances of success are higher and the costs of intervention are lower in conflicts located closer to home.

The paper is organized as follows. Sections 2 and 3 describe the sample and present potential determinants of UN intervention decisions. Section 4 introduces our empirical methodology and section 5 presents our findings. Section 6 discusses and tests alternative explanations and section 8 concludes the paper. 


\section{Conflicts and Interventions}

Between 1950 and 2012, the Uppsala Conflict Data Program (UCDP) notes the beginning of 199 armed conflicts worldwide. We use the conflict identifier in the UCDP/PRIO Armed Conflict Dataset, available at http://www.pcr.uu.se/research/ucdp/datasets, going back to Gleditsch et al. (2002). The UCDP defines conflict as

a contested incompatibility that concerns government and/or territory where the use of armed force between two parties, of which at least one is the government of a state, results in at least 25 battle-related deaths.

These conflicts are categorized as interstate, internal, and internationalized internal armed conflicts. Interstate conflicts are defined as taking place between two governments, whereas the UCDP defines an internal conflict as being between

a government of a state and one or more internal opposition group(s) without intervention from other states.

Finally, an

[i]nternationalized internal armed conflict occurs between the government of a state and one or more internal opposition group(s) with intervention from other states (secondary parties) on one or both sides.

Our analysis excludes extrasystemic armed conflicts between a state and a non-state group outside of its own territory, as the UN did not intervene militarily in any of these.

We choose conflicts that began after 1949, because that is when broad comparable data on the country level becomes available. We capture the characteristics of a country at the beginning of the conflict, which will be explained in section 3. Our main sample consists of 174 conflicts for which information on all main variables is available. Table A.1 lists all conflicts and interventions in addition to marking the 25 conflicts for which we do not have data. Most conflicts for which data is unavailable occurred in Asia (17). However, we find no statistically significant difference in terms of intervention probability between the sample conflicts and the remaining 25 conflicts. Notice that there are several double entries, meaning that some countries 
incurred various conflicts within a year. However, we were able to match each intervention with the targeted conflict.

In terms of UN interventions, we distinguish between four types of action: ${ }^{2}$

1. Military intervention for peacebuilding,

2. Military intervention for peacekeeping,

3. Sanctions or embargoes, and

4. Demands to cease hostilities or to establish an observer mission.

Throughout the majority of the paper, we define military actions - cases 1 and 2 - as interventions, following previous literature. The remaining two types of action are usually associated with substantially lower commitment levels, in economic, military, and political terms. Therefore, we code these as non-interventions for now. In our final sample of 174 conflicts, the UN conducted military interventions in 40.

Figure 1 shows conflicts and UN interventions, and we notice that the overwhelming majority of conflicts in the second part of the 20th century occurred on the African and Asian continents. The raw intervention probability in Africa stands at a remarkable 31.6 percent rate, whereas Asian conflicts show substantially smaller chances of UN intervention at 12.5 percent. Previously, Bariagaber (2008) documented that there have been more UN interventions in Africa since the late 90s. The formation of the post-Soviet states and the dissolution of Yugoslavia marked a series of European conflicts in the early 1990s.

Figure 2 then displays the relationship between the conflict intensity and the number of UN interventions, showing whether the country had at least one conflict year with over 999 battlerelated deaths. This cutoff is provided in the UCDP database to identify particularly violent conflicts. Especially Central and East African, but also Asian and South American conflicts, have been marked by at least one such violent year. In contrast to this basic comparison is the frequency of interventions, however, which appears to suggest a focus on African, Eastern European, and a few Middle Eastern and Asian countries. One should keep in mind, though,

\footnotetext{
${ }^{2}$ What the UN means by "intervention" is not entirely clear, as there exists no single definition. Higgins (1995) provides a deeper discussion.
} 
that these maps do not account for other important factors beyond intensity and could therefore be misleading.

\section{Potential Determinants of UN Intervention}

Our main estimations consider four general categories of potential factors associated with UNSC interventions: The conflict characteristics, but also social and historical, macroeconomic, and geographical factors. Including our robustness checks, the analysis incorporates data from 8 different sources to analyze the factors associated with UN intervention decisions: The UN, the UCDP, PWT version 7.1, Polity IV, the Affinity of Nations index, the Correlates of War, and the Quality of Government data sets. The following sections describe the variables of the main analysis in turn, and table A.2 provides details on all variables used in our analysis with their respective sources.

\subsection{Conflict Characteristics}

All conflict related variables are taken directly from the UCDP data set. First, we include a binary variable for the intensity of the conflict, coded as one if the conflict had at least one year with over 999 battle-related deaths. ${ }^{3}$ We would assume that the intervention probability would increased with a greater number of vistims (see Gilligan et al., 2003). Ideally, we would like to include a more precise and continuous measurement of conflict intensity, but information on the exact number of conflict victims is scarce and usually comes with great uncertainty and large lower and upper boundaries. Thus, we would lose a substantial number of observations if we were to include a more defined measurement for conflict intensity. In addition, we control for the type of conflict, distinguishing between interstate, internal, and internationalized armed conflicts. Jakobsen (1996) discusses both the intensity and the conflict type as potential determinants of UN peace enforcement missions.

\footnotetext{
${ }^{3}$ There are, of course, different ways to measure the intensity, such as the fraction of conflict years with over 999 battle-related deaths, etc. Our results are robust to using different measurements.
} 


\subsection{Social and Historical Factors}

Social components of countries, and especially their historical ties to traditional Western nations, could be important factors in UN intervention decisions. We control for population size, which has the potential for two primary intuitions (see Melander, 2009, for instance). First, a bigger society means a bigger potential human loss in a conflict. Second, the more people live in a country, the more potential soldiers there are, which may lower the chances of success and raise the costs of an intervention. The first argument promotes a positive relationship between population size and the probability of intervention, whereas the second argument suggests a negative effect (see also Alesina and Spolaore, 2005). To facilitate comparability and contain the influence of outliers, we apply the natural logarithm to population size throughout all estimations.

In terms of historical relationships to the colonial powers, we also add information about the former colony status of the conflict nation. Specifically, we incorporate dummies for French, Portuguese, and Dutch colonies (Gilligan et al., 2003). Including binary variables for British or Spanish colonies never returned significance, and their inclusion does not affect our conclusions.

\subsection{Macroeconomic Factors}

The economic environment of a conflict nation may play an important role in the UN's decision to intervene militarily. First, we include GDP per capita at the inception of the conflict to capture the basic development level of the country. The humanitarian aspect of including GDP per capita states that the UN may be more inclined to protect those people who are unable to protect themselves, which many times includes the poor. In this context, we also refer to the "R2P" (Responsibility to Protect) initiative, formalized by the UN in 2005. Further, the opportunity cost of joining an army could be smaller when general income possibilities in a country are low. Thus, potential fatalities could be higher in poorer nations, everything else equal. Finally, there may be a practical argument for considering income levels in UNSC decisions: An intervention could be both cheaper and more likely to succeed in poorer nations because military and technical resources are likely to be less developed.

Second, we consider a country's openness to international trade, measured as the share

of exports plus imports in GDP. Theoretically, conflict countries with stronger international economic ties could be prioritized by the UN, as other countries may be economically affected 
by the conflict (also consider Martin et al., 2012, in this context). Thus, there could be a stronger international interest in intervening in more open countries. Section 4 also considers bilateral trade flows between the five permanent members and the conflict nation.

For both GDP per capita and trade openness, we use values at the starting year of the conflict to allow for better data availability, as opposed to one year prior to the conflict. Further, we apply the natural logarithm to both variables, as is common in the macroeconomics literature. All findings are robust to using lagged values or to refraining from applying logarithms. The data for both income levels and trade openness come from the PWT 7.1 and is supplemented by the World Bank, if the PWT 7.1 does not contain information (see tables A.1 and A.2 for details).

\subsection{Geographical Factors}

In terms of geography, we include the geographical distance of the conflicts to the five permanent UNSC members: China (chidist), France (fradist), Russia (rusdist), the UK (ukdist), and the US (usdist). These nations have been shown to possess overwhelming power in UNSC decisions, both directly through their veto power and indirectly through their dominant political and economic roles, e.g., by O’Neill (1996).

All distances are calculated as the minimum distance between the border of the conflict country and the reference nation in 1,000 kilometers. Therefore, countries that share a common border receive a value of zero, for instance in the case of Afghanistan and its distance to China. It is important to mention that we use the distance to the former Soviet Union before 1991 and then Russia thereafter. However, using the distance to today's Russia for the entire time period does not change our conclusions. Similarly, we choose the distance to Taiwan for chidist until 1971, as the official government of China was located on the island until then. Here also, our conclusions regarding chidist do not change if we use the distance to Mainland China throughout the entire time period.

We then condense these five distance measures to two variables: westdist, capturing the distance of the closest Western UNSC permanent member (France, the UK, or the US), and eastdist, calculated as the minimum distance to the Eastern permanent members of the UNSC (China or Russia). However, all derived results are robust to using the individual distance 
variables.

Finally, we follow Gilligan et al. (2003) by considering continental fixed effects for Africa, Asia, Europe, and Latin America. Using other geographical aspects, such as binary variables for landlocked and island countries, never reach conventional significance levels; including them does not change our conclusions and these results are available upon request.

\section{Methodology}

Throughout the paper, we apply a logit regression framework to estimate the probability $p_{i}$ of a UN military intervention in conflict $i$ by

$$
\operatorname{logit}(p)_{i}=\alpha_{0}+\boldsymbol{X}_{\boldsymbol{i}}^{\prime} \alpha_{1}+\boldsymbol{Z}_{\boldsymbol{i}}^{\prime} \alpha_{2}+\boldsymbol{G} \boldsymbol{E} \boldsymbol{O}_{\boldsymbol{i}}^{\prime} \alpha_{3}+\delta_{i} .
$$

$\boldsymbol{X}_{\boldsymbol{i}}$ incorporates the intensity (intense) and form (interstate and internal, with internationalized as the reference) of the conflict. $\boldsymbol{Z}_{\boldsymbol{i}}$ contains population size (lnpop), GDP per capita (lngdp), and openness to trade (lnopen) in the starting year of the conflict, in addition to colony fixed effects. All derived results are robust to using values one year before the conflict beginning for the time-varying components of $\boldsymbol{Z}_{\boldsymbol{i}}$. $\boldsymbol{G E} \boldsymbol{O}_{\boldsymbol{i}}$ contains one of the five distances to the permanent UNSC members or westdist and eastdist, in addition to continental fixed effects. Finally, $\delta_{i}$ captures the usual error term.

Section 6 considers alternative explanations for the main results, adding to equation 1 accordingly. All derived results are robust to using a probit framework.

\section{The Probability of Intervention}

Table 1 shows the main results from estimating equation 1, where we include the distance to each of the five permanent UNSC members in turn. The final column includes distances to the closest Western (westdist) and Eastern (eastdist) permanent UNSC members. Table 1 and all following tables display marginal effects, log-likelihood values, and Chi-squared values. Further, figures 3 to 6 visualize the derived results in terms of predicted probabilities. 


\subsection{Results from Logit Estimations}

Starting with the conflict characteristics, we find that having at least one year with over 999 battle-related deaths raises the probability of intervention by approximately 14 to 16 percent (intense). This finding remains consistent throughout the paper. The form of conflict, however, appears to matter less, although internationalized conflicts (the omitted category) are weakly suggested to receive priority.

Further, interventions are more likely in smaller and poorer nations. Regarding a quantitative interpretation, our most complete specification displayed in column (6) proposes an 8.2 percentage point decrease in the intervention probability once GDP per capita is doubled. Openness to trade, however, does not appear to matter, as the suggested coefficient is negative but not significant. Considering continental effects, we find no evidence for a preference across continents and this result remains consistent throughout all our estimations.

Moving to geographical distances, proximity to the West appears to play a significant role. Distances to France, the UK, and the US are statistically significant predictors of intervention. The negative sign suggests that the probability of a military intervention by the UN decreases with distance. The coefficients for the distances to China or Russia, however, are never close to conventional significance levels. Column (6) then includes the minimum distances to the Western

(westdist) and Eastern powers (eastdist). Confirming the importance of the individual distance measurements, every 1,000 kilometers of distance from the West reduce the chances of a UN intervention by 4 percent. This result means that the probability of intervention is suggested to be $42-43$ percentage points lower in a country like Malaysia or Indonesia as opposed to any country bordering France, the UK, or the US, such as Mexico or Spain. The regressions displayed in table 1 also show that the distance finding cannot be explained by continental preferences, as Gilligan et al. (2003) previously suggested a regional bias of UN interventions against Asian conflicts.

\subsection{Predicting UN Interventions}

Figures $3-5$ provide estimated probabilities relative to westdist for different conflict scenarios, where other explanatory variables are assumed at their sample means. These figures also display the two-sided 95 percent confidence interval. In the case of an intense internal conflict, the 
estimated probability of intervention reaches over 50 percent for any country adjoining France, the UK, or the US. For a country with over 10,000 kilometers of distance however, like Malaysia or Indonesia, the probability approaches zero. Results for interstate and internationalized conflicts are similar.

In terms of predicting the probability of interventions, we now use data from PWT 7.1 for all available countries for the year 2010 and not only our sample countries. Assuming a hypothetical intense (over 999 battle-related deaths) internal conflict, we use our primary results from table 1, column (6), to calculate the predicted probability of a military intervention by the UN. ${ }^{4}$ Note that African countries generally appear to enjoy higher odds of intervention than Asian or even European countries. Angola, Guinea-Bissau, São Tomé and Príncipe, and Somalia stand out with probabilities over 85 percent. In these cases, poverty and population size are the driving factors. Similarly, the small nations in the Northeast of South America (Guyana, Suriname, and French Guiana) also receive a high likelihood. Especially the Eastern European nations from Estonia in the North to Greece in the South display stronger probabilities - a result that is partially driven by their geographical proximity to Western Europe. Although this exercise is, of course, speculative, these results shed some interesting light on the predicted patterns of intervention.

\section{Alternative Explanations}

This importance of westdist in the probability for a military intervention by the UN is startling. However, it may well be possible that these findings are spurious and the result of an omitted variable bias. In this case, the lack of a clear theoretical framework that could provide guidance for the true model leaves room for additional hypotheses. One could think of various explanations, and the following list is surely not complete, as the real reasons for UNSC resolution decisions are difficult to retract. This difficulty is true in intervention cases, but even more so in non-intervention decisions. The real motivations behind political decisions, especially on the global stage, are sometimes only identified decades later, if ever. Overall, we distinguish between three broad alternative explanations for these distance findings: Political, economic,

\footnotetext{
${ }^{4}$ The predicted probabilities are calculated as probiv $=\frac{1}{1+e^{-\log i t(p)}{ }_{i}}$ following Greene (2003).
} 
and practical considerations. However, some theories, such as the importance of foreign aid for instance, may fit in several categories. Naturally, we are not only interested in explaining the distance finding, but also in the individual effect of these variables on intervention decisions. Although we proceed with using westdist and eastdist, all conclusions are closely replicable using the individual distances to the five permanent member states.

\subsection{Political Factors}

Tables 2 and 3 show a variety of extensions, taking into account the various political circumstances after 1949 and the UN voting habits of the conflict nations in relation to the five permanent UNSC members.

First, the period from 1950 to 2012 was marked by major political disputes between the five permanent UNSC members as well as within each of these nations. We focus on three major aspects of these relationships that existed throughout this time period. First, the Cold War period clearly shaped global political decisions, especially between the Soviet Union and the US. For instance, Gilligan et al. (2003) and Wallensteen (2011) suggest that UN interventions were generally less likely during the Cold War period. Second, some conflicts stand out in relation to the five permanent members, such as the Yugoslav wars in the heart of Europe, the conflicts associated with the collapse of the Soviet Union, or conflicts in the member states themselves. We want to make sure that these special conflicts do not drive our results. Third, following Andersson (2000) and Melander (2009), we include the political regime form of the

conflict country using the Polity IV variable, which ranges from -10 (total autocracy) to +10 (total democracy). Because the UN focuses particularly on protecting those who cannot protect themselves, this philosophy may well apply to non-democratic oppressive regime systems. Table 2 considers each of these events, using column (6) of table 1 as the reference point and the most complete specification.

In column (1), we include a dummy variable for conflicts that started during the Cold War period, whereas in column (2) we re-estimate our main regression excluding conflicts that began after the Cold War ended. Columns (3) and (4) repeat these exercises excluding conflicts on the European continent and within the five permanent members. Column (5) includes a dummy 
for conflicts in which any of the five permanent members participated individually. ${ }^{5}$ Finally, column (6) controls for the democracy level of the conflict country in the beginning year of the conflict. ${ }^{6}$

We find several noteworthy results from these extensions. First, the distance to the Western powers remains important. In fact, significance levels and magnitudes mostly even increase compared to our baseline estimation from table 1. Distance to the East, however, remains a non-factor. The remaining coefficients confirm the baseline findings throughout all extensions. Finally, UN interventions appear to be more likely in non-democratic countries, confirming findings by Stojek and Tir (2011), and nations in which one of the five permanent members also intervened independently of the UN. Although the Polity score represents a crude measurement of the citizens' opportunity to participate politically, these results confirm the UN's "Responsibility to Protect" initiative.

Another measurement of the political relationship between conflict countries and the five permanent members comes from the "Affinity of Nations" data set (Voeten and Merdzanovic, 2013). Following Fortna (2008) and Stojek and Tir (2011), this data set allows us to include a voting similarity index between the conflict nation and each of the five permanent UNSC members in UN resolutions, ranging from 0 to 1 (variable agree3un in data set). Table 3 shows the results when including each of these scores in turn. Column (6) then includes the maximum affinity score with the Western (affwest) and the Eastern permanent UNSC members (affeast). The main takeaway from these regressions is that none of the affinity scores has an impact on the intervention probability. With respect to the distance findings, westdist remains significant throughout table 3. Only in column (3) does the magnitude drop to 0.32 , potentially due to the loss of 43 observations when including the affinity score to the Russian UN voting behavior. The coefficients of the remaining control variables are not displayed from here on, as their significance and magnitudes confirm the main results from table 1.

In summary, the political explanations presented in this section are unlikely to drive the importance of the geographical distance to the West in UN military intervention decisions.

\footnotetext{
${ }^{5}$ We use the list of participating nations in the UCDP data set to identify conflicts in which the permanent members participated.

${ }^{6}$ As with other time-varying variables, using values from one year prior to the conflict does not affect our conclusions.
} 
However, some political aspects do have an independent relationship with UNSC decisions, such as the democracy level of the regime in general or the Cold War period in particular. In additional estimations, we also incorporated the possibility of several other political attributes, such as membership in the Warsaw Pact, being a nuclear power, and membership in regional associations (e.g., the South Asian Association for Regional Cooperation, SAARC). None of these appear to be important in their own right or to affect the importance of westdist.

\subsection{Economic Factors: Bilateral Trade, Foreign Aid, and Distance to Oil Suppliers}

Turning to economic characteristics, we now consider bilateral trade relationships, foreign aid flows, and the geographical distance of the conflict nation to major oil supplying countries. Here again, we are both interested in the individual connection between these variables and the probability of UN interventions, but also whether their inclusion is able to explain the importance of westdist.

First, we take a closer look at international trade aspects. Although our primary analysis incorporates overall trade openness, the specific trade relationship with the five permanent members could be of particular importance, leading us to include bilateral trade flows. ${ }^{7}$ Previously, Stojek and Tir (2011) suggested that the economic interests of major powers play a decisive role in UN peacekeeping decisions, although Perkins and Neumayer (2008) finds no importance for the participation of individual nations in international peacekeeping operations. From an individual country's perspective, it would be understandable if the inclination to promote an intervention was stronger for countries with which it maintains strong trade relationships. Similarly, foreign aid flows to developing nations (which the majority of the conflict countries are) provide a measure of increased interest and concern from the West about the specific country.

Table 4 considers these variables in turn. Specifically, we include the natural logarithm of exports to (and imports from) the US in the beginning year of the conflict, adjusted by the US price level at the time. We then add the total exports to (and imports from) France, the UK, and the US in columns (3) and (4). Interestingly, we find weak evidence of stronger trade

\footnotetext{
${ }^{7}$ Bilateral trade data comes from the Correlates of War data set (see Barbieri et al., 2009, and Barbieri and Keshk, 2012).
} 
relationships decreasing the odds of intervention - a somewhat counterintuitive result. Moving to the final two columns of table 4, we include the natural logarithm of net foreign aid received by the conflict country at the beginning of the conflict, first in overall terms and then from the US only. Similar to bilateral trade flows, we see no change in our main results, suggesting that the distance findings are not driven by foreign aid flows. In this case however, it is important to note that we are losing up to 56 observations due to the unavailability of data. The findings presented in table 4 are virtually identical if we use trade (foreign aid) relative to population or GDP.

Finally, we also consider the extraordinary importance of oil in the world economy, especially for the Western powers. As numerous conflicts in the second half of the twentieth century have been fought in or close to major oil supplying nations, one could suspect these concerns may enter UNSC discussions, at least behind closed doors. Thus, we also test whether the distance of the conflict to major oil suppliers plays a role in determining the intervention probability. ${ }^{8}$ Table 5 shows these results, adding distances to Saudi Arabia, Iraq, Iran, Kuwait, and Venezuela to our baseline regression. Interestingly, none of these distances matters and westdist remains a powerful predictor of UN interventions. Finally, column (6) of table 5 introduces the distance to Israel, given the country's importance in world politics ever since its foundation. However, we find no importance for isrdist either.

In summary, it appears unlikely that economic factors are driving the importance of westdist. Neither bilateral trade flows nor foreign aid nor distances to major oil suppliers are able to account for the importance of the geographical distance to the West in UN intervention decisions. As a last category of possible explanations, we now turn to practical aspects.

\subsection{Practical Considerations: Chances of Success, Costs, and Feasibility}

Beyond political and economic explanations for the distance finding, we further consider practical reasons as a third option. It could simply be less expensive and more convenient to intervene in a conflict nearby as opposed to a conflict located thousands of kilometers away. Unfortunately, it proves to be difficult to test this alternative hypothesis directly: Even though we may observe the expected costs and circumstances of a realized UN intervention at the beginning, we cannot

\footnotetext{
${ }^{8}$ Table A.3 provides correlations between all distance measures used.
} 
observe these considerations in the case of non-interventions.

Another practical reason for the importance of westdist may be given by the chances of success. The likelihood of an operation being successful could be higher in conflicts closer to home (see Jakobsen, 1996) because, for example, it is easier and quicker to move troops. In fact, one possible interpretation of why the UN is more likely to intervene in poorer and smaller countries is that the chances for success are higher and the expected costs are lower. With a poorer society comes potentially inferior weapon technologies and generally fewer resources for resistance. Similarly, a smaller population signals a conflict that is easier to oversee and shows less room for expansion, all else being equal.

In the following, we discuss several alternative estimations, attempting to filter out whether practical considerations may be responsible for the importance of westdist.

\subsubsection{Redefining Intervention}

To get an idea as to whether costs or success probability could play a role in UNSC decisions, we first take advantage of other forms of UN interventions beyond military operations. It may be understandable that costs and the success chances of a military intervention change with geographical distance, but these considerations should not apply when considering other types of interventions, such as imposing economic sanctions, embargoes, calling for an end of hostilities, or sending observer missions. None of these weaker forms of intervention are associated with a substantial commitment of resources. Thus, if westdist does not play a role in nonmilitary interventions, this would signal that geographical distance matters solely for military interventions, which are associated with a much larger commitment of resources.

Table 6 replicates table 1, this time including the non-military forms of intervention in the intervention definition $(a n y I V)$. We notice that the distance findings are substantially weakened, as ukdist and usdist are no longer significant at conventional levels. Only westdist remains significant at the ten percent level. Thus, geographical proximity may not matter for non-military UN interventions. Another sign that practical considerations may be less important is that $\operatorname{lng} d p$ loses significance in these estimations.

However, categorizing a military peacekeeping intervention in the same way as a call to end hostilities may oversimplify the concept of a UN intervention. It is difficult to relate these 
types of interventions. For instance, it is impossible to generalize that two, three, or four sanctions represent the equivalent of one military intervention. Although imperfect, table 7 then ignores military interventions for a moment and solely considers those conflicts in which the UN never intervened militarily. For these cases, we code non-military operations by the UN (nonmilitary $I V)$ as an intervention, and all conflicts where the UN did not intervene in any form are coded as zeros. In fact, nonmilitary and military interventions show no statistically significant difference in terms of westdist. Using the usual control variables then shows that distances completely lose their importance, both in terms of significance and magnitude. One interpretation of this finding is that the practical considerations in terms of costs and the probability of success could indeed explain the importance of westdist for military interventions by the UN. Another indication for the importance of practical considerations can be found in the remaining coefficients throughout table 7: Population size does not matter for non-military interventions and the sign corresponding to GDP per capita is, in fact, reversed. The weaker types of intervention appear to be more likely in richer states. The signs on lngdp are positive throughout and reach conventional significance levels in three out of six regressions.

From an econometric perspective, of course, the danger of a selection bias exists in table 7 because it excludes those conflicts that received military interventions by the UN. Thus, the results displayed in tables 6 and 7 should be interpreted with care. The upcoming section will now include other aspects in our main estimation that might be related to practical considerations.

\subsubsection{Military Opposition, Year of Conflict, and Other Interventions}

Columns (1) - (3) of table 9 consider three additional tests for the importance of practical considerations in UNSC decisions. First, we include the Composite Index of National Capability score (cinc) from the Correlates of War data set (version 4.0 built on Singer et al., 1972, and Singer, 1988). The military strengths and capabilities of the conflict country may well influence the chances of success for a potential UN intervention. Thus, it is important to test whether military strength is an important intervention determinant in itself, but also whether cinc can explain the distance finding. Indeed, military strength proves to affect the chances of intervention negatively, although this finding is not significant. Beyond that, the coefficient on westdist remains virtually unchanged. 
Second, column (2) includes a basic time trend in our main estimation, incorporating the beginning year of the conflict. As both weapons' and information technology advanced rapidly over the past decades, a potential intervention today could be cheaper and easier to plan, but it may also be easier to foresee the chances of success. However, column (2) shows that year remains firmly insignificant. Similarly, including a squared time trend does not appear to matter (results not displayed, but available upon request).

Finally, considerations regarding costs and success probabilities may be reflected in both the number of ongoing interventions by the UN at the beginning of the conflict (currentivs) and whether the conflict country was subject to a previous military intervention (ivprev). With more military commitments already in progress, budget constraints may become more important, therefore lowering the chances of starting a new operation. Interestingly, the number of current interventions appears to have a positive effect on intervention decisions.

In terms of success probability, a previous intervention may be helpful for knowing the country and the specific conflict at stake. In addition, previously installed facilities could be used or local contacts from the previous operations could be utilized. However, ivprev has no significant impact. Also, the importance of westdist remains once again robust to these extensions.

\section{Robustness Checks}

Beyond the possible explanations of the importance for distance from the West, we now consider several robustness checks for our main estimation of table 1, column (6). Table 8 then asks whether additional spatial aspects should be included in our baseline model. Finally, table 9 addresses the relationship between the conflict country and the UN, but also the conflict duration and the religious composition of the conflict country.

\subsection{Additional Spatial Components}

In our main estimations, the spatial components consist of the distance to the five permanent UNSC members and continental dummies. However, it may well be possible that other spatial aspects of the conflict nation play a role in determining UNSC intervention decisions. To test 
for any further spatial characteristics that might be present in the data, we first create a spatial cross-section in which each observation unit is a country. There is therefore one observation for every country that had at least one conflict since 1950 (IV spatial). Consequently, we also collapse the explanatory variables. As for the intensity of the conflict, we code this variable as equal to one if the country experienced at least one year with more than 999 deaths in any of its conflicts (maxintense). Regarding the conflict form, we count the number of internal and interstate conflicts (ninternal and ninterstate) and include both of these variables in the regression. As for population size, GDP per capita, and trade openness, we calculate the average of these values for every conflict country at the beginning of their conflict (lnpopavg, lngdpavg, and lnopenavg). This pure cross-sectional data set then consists of 94 entries, i.e., 94 countries. $^{9}$

The question we are asking in this extension is whether the probability of military intervention by the UN in a conflict country is affected by intervention decisions in neighboring countries. ${ }^{10}$ We run a classic non-spatial Probit model and assess the presence of spatial error autocorrelation, with the results displayed in table 8. If we found such evidence, then spatial Probit models should be preferred over our logit estimations because ignoring spatial error autocorrelation in the error term would result in inefficiency and inconsistency of the maximum likelihood estimator (Amaral et al., 2012). The literature on tests for spatial error autocorrelation exhibits three main versions after Pinkse and Slade (1998), Kelejian and Prucha (2001), and Pinkse (2004). However, these tests have crucial differences regarding the sample size. Amaral et al. (2012) shows that the generalized Moran's I statistic (MI) devised by Kelejian and Prucha (2001) achieves its asymptotic distribution in sample sizes as small as N=49 and is not affected by spatial correlation in the regressors. The other two statistics require large sample sizes, in the order of thousands, to achieve their asymptotic distributions and are slightly affected by spatial correlation in the regressors. ${ }^{11}$ Thus, we opt for the generalized Moran's I statistic $(M I)$.

Specifically, we use the module spreg.probit in the PySAL library (Rey and Anselin, 2010) to run the classic non-spatial Probit and the $M I$ test using the spatial version of our data described above. The results from these estimations are reported in table 8, displaying marginal effects. First, we note that the distance findings from table 1 receive strong support, both in terms

\footnotetext{
${ }^{9}$ Data set is available upon request.

${ }^{10}$ By neighbors, we mean countries that share a common border with the conflict nation.

${ }^{11}$ See Amaral et al. (2012) for a complete description.
} 
of significance and magnitudes, which are even greater for the Western permanent members. As before, conflict intensity matters, whereas conflict form remains an insignificant predictor. Also, the previous conclusions for the remaining variables are generally confirmed. Finally, the $M I$ test results then show no clear evidence for the presence of spatial error autocorrelation. ${ }^{12}$ Thus, the probability of military intervention by the UN does not appear to depend on previous interventions in neighboring countries.

\subsection{Relationship to the UN, Conflict Duration, and Religious Orientation}

Columns (4) - (7) of table 9 consider other attributes of the country and its conflict. First, we include a binary variable for conflict countries that were members of the UN at the inception of the conflict (unmember). We then add a dummy variable for conflict countries that formed part of the UNSC as a non-permanent member at any time during the conflict. Both of these variables reflect the basic relationship between the conflict country and the UN and may therefore enter the decision-making process at the UNSC. Interestingly, the probability of intervention is reduced by over 15 percentage points if a conflict country was a member of the UNSC at any time during the conflict. However, this finding does not explain the importance of geographical distance.

Further, column (6) includes the total duration of the conflict in months (see Gilligan et al., 2003, and Fortna, 2004). Even though this estimation may raise endogeneity issues in the form of reverse causality (not only could the conflict duration affect the probability of UN intervention, but a UN intervention could also affect the conflict duration), the conflict duration does not appear to matter. Finally, column (7) turns to the religious composition of the conflict country. We use the fractions of Catholic, Muslim, and Protestant citizens in society, as measured in 1980, to see whether religion is associated with the intervention probability. However, the results reject this idea and once again leave the coefficient associated with westdist virtually unchanged.

\footnotetext{
${ }^{12}$ A significant p-value for the $M I$ test indicates that the residuals of the regression are spatially autocorrelated, but the test does not discriminate between the error or lag dependence.
} 


\section{Concluding Remarks}

Political decisions are often made behind closed doors, and many times their true intentions are difficult to expose. This quality also holds for the United Nations Security Council's decisions about military interventions. This paper builds on an insightful stream of research by trying to discover the true aspects associated with these interventions. Our findings indicate that military interventions are more likely in countries that are located closer to the three Western permanent UNSC members (France, the UK, and the US) but also in poorer and smaller countries.

In theory, the geographical distance to the deciding powers in the Council should not be a significant factor behind UNSC intervention decisions. Distance may well be justifiable for intervention decisions by single countries or regional organizations because their focus lies on protecting domestic borders. However, the United Nations emphasizes its equal commitment to all 193 member states. Our most complete estimations suggest that for every 1,000 kilometers of distance to the closest Western permanent member, the probability of a military UNSC intervention decreases by approximately 4 percent. In the case of Malaysia or Indonesia, this represents a reduction of almost $42-43$ percentage points, compared to a country bordering one of the three Western powers (e.g., Mexico or Spain). Interestingly, the distance to the Eastern permanent members (China and Russia) does not matter. It is also noteworthy that we do not find any intervention preferences along the lines of continents.

There are, of course, numerous alternative explanations, and the paper tests for a variety of them. Among these, we generally distinguish between political, economic, and practical aspects. In terms of politics, we take into account the Cold War period, the extraordinary role of the European conflicts (the Yugoslavian Wars and the formation of the post-Soviet Union states), the regime form, and the affinity scores in UN voting behavior. None of these are able to explain the distance finding. As for independent effects, we find that interventions are more likely in less democratic regimes - a finding that confirms the "R2P" initiative (Responsibility to Protect), as recently formalized by the UN. Regarding economic reasons, we incorporate bilateral trade relationships between the conflict country and the permanent members, foreign aid flows, and the distance to major oil suppliers. Again, none of these aspects are able to account for the importance of geographical distance.

However, we find evidence for the importance of practical considerations from additional es- 
timations, where we broaden the intervention definition to non-military actions (e.g., embargoes, sanctions, or establishing observer missions). Beyond the difference in the severity of an intervention, which is difficult to quantify, these weaker forms of intervention have in common their substantially lower level of commitment, both in terms of personnel and of general resources. Indeed, we find that once we define intervention more broadly, the distance finding weakens. In fact, a hypothetical exercise in disregarding those conflicts that received military interventions by the UNSC produces different results. In these estimations, neither the geographical distance to the West nor country size nor GDP per capita decrease the intervention probability. If anything, it appears as if these weaker intervention forms are more likely to happen in richer nations. These results add to the notion that it is only military intervention decisions by the UNSC that are driven by practical considerations.

Of course, these final estimations must be interpreted with caution. Whether the UN sends military troops for peacekeeping or imposes an embargo constitutes a major difference in commitment level. Thus, pooling these actions may oversimplify the question and wash out these important differences. Similarly, disregarding the conflicts that were subject to UN military interventions at some points could introduce a selection bias.

\section{References}

Alesina, A. and Spolaore, E. (2005). War, peace, and the size of countries. Journal of Public Economics, 89(7):1333-1354.

Amaral, P. V., Anselin, L., and Arribas-Bel, D. (2012). Testing for spatial error dependence in probit models. Letters in Spatial and Resource Sciences, pages 1-11.

Andersson, A. (2000). Democracies and UN peacekeeping operations, 1990-1996. International Peacekeeping, 7(2):1-22.

Aydin, A. (2010). Where do states go? Strategy in civil war intervention. Conflict Management and Peace Science, 27(1):47-66.

Barbieri, K. and Keshk, O. (2012). Correlates of war project trade data set codebook. Codebook Version, 3 . 
Barbieri, K., Keshk, O. M., and Pollins, B. M. (2009). Trading data evaluating our assumptions and coding rules. Conflict Management and Peace Science, 26(5):471-491.

Bariagaber, A. (2008). United Nations peace missions in Africa transformations and determinants. Journal of Black Studies, 38(6):830-849.

BBC (2004). UN chief's Rwanda genocide regret. http://news.bbc.co.uk/2/hi/africa/ 3573229.stm.

Childers, E. (1994). Empowering the peoples in their United Nations. http://www . globalpolicy.org/component/content/article/228/32395.html.

Dreher, A., Sturm, J.-E., and Vreeland, J. R. (2009a). Development aid and international politics: Does membership on the UN Security Council influence World Bank decisions? Journal of Development Economics, 88(1):1-18.

Dreher, A., Sturm, J.-E., and Vreeland, J. R. (2009b). Global horse trading: IMF loans for votes in the United Nations Security Council. European Economic Review, 53(7):742-757.

Fortna, V. P. (2004). Does peacekeeping keep peace? International intervention and the duration of peace after civil war. International Studies Quarterly, 48(2):269-292.

Fortna, V. P. (2008). Does peacekeeping work?: Shaping belligerents' choices after civil war. Princeton University Press.

Gilligan, M. et al. (2003). Where do the peacekeepers go? International Studies Review, $5(4): 37-54$.

Gleditsch, N. P., Wallensteen, P., Eriksson, M., Sollenberg, M., and Strand, H. (2002). Armed conflict 1946-2001: A new dataset. Journal of Peace Research, 39(5):615-637.

Greene, W. H. (2003). Econometric analysis-international edition. New York University.

Higgins, R. (1995). Problems and process: International law and how we use it. Oxford University Press.

Jakobsen, P. V. (1996). National interest, humanitarianism or CNN: What triggers UN peace enforcement after the Cold War? Journal of Peace Research, 33(2):205-215. 
Kelejian, H. and Prucha, I. R. (2001). On the asymptotic distribution of the moran / test statistic with applications. Journal of Econometrics, 104(2):219-257.

Kuziemko, I. and Werker, E. (2006). How much is a seat on the security council worth? Foreign aid and bribery at the United Nations. Journal of Political Economy, 114(5):905-930.

Martin, P., Mayer, T., and Thoenig, M. (2012). The geography of conflicts and regional trade agreements. American Economic Journal: Macroeconomics, 4(4):1-35.

Melander, E. (2009). Selected to go where murderers lurk? The preventive effect of peacekeeping on mass killings of civilians. Conflict Management and Peace Science, 26(4):389-406.

Mullenbach, M. (2005). Deciding to keep peace: An analysis of international influences on the establishment of third-party peacekeeping missions. International Studies Quarterly, 49(3):529556.

Mullenbach, M. J. and Matthews, G. P. (2008). Deciding to intervene: An analysis of international and domestic influences on United States interventions in intrastate disputes. International Interactions, 34(1):25-52.

Neack, L. (1995). UN peace-keeping: In the interest of community or self? Journal of Peace Research, 32(2):181-196.

Oatley, T. and Yackee, J. (2004). American interests and IMF lending. International Politics, 41(3):415-429.

O'Neill, B. (1996). Power and satisfaction in the United Nations Security Council. Journal of Conflict Resolution, 40(2):219-237.

Pearson, F. (1974). Geographic proximity and foreign military intervention. Journal of Conflict Resolution, 18(3):432-460.

Perkins, R. and Neumayer, E. (2008). Extra-territorial interventions in conflict spaces: Explaining the geographies of post-cold war peacekeeping. Political Geography, 27(8):895-914.

Pinkse, J. (2004). Moran-flavoured tests with nuisance parametrics: Examples. Advances in Spatial Econometrics: Methodology, Tools and Applications. 
Pinkse, J. and Slade, M. E. (1998). Contracting in space: An application of spatial statistics to discrete-choice models. Journal of Econometrics, 85(1):125-154.

Rajan, S. C. (2006). Global politics and institutions. GTI Paper Series: Frontiers of a Great Transition.

Rey, S. J. and Anselin, L. (2010). Pysal: A Python library of spatial analytical methods. In Handbook of Applied Spatial Analysis, pages 175-193. Springer.

Singer, J. D. (1988). Reconstructing the orrelates of war dataset on material capabilities of states, 1816-1985. International Interactions, 14(2):115-132.

Singer, J. D., Bremer, S., and Stuckey, J. (1972). Capability distribution, uncertainty, and major power war, 1820-1965. Peace, war, and numbers, pages 19-48.

Stojek, S. and Tir, J. (2011). Supply side of United Nations peacekeeping operations: Economic ties and locations of UN-led deployments. In APSA 2011 Annual Meeting Paper.

Teorell, J., Samanni, M., Holmberg, S., and Rothstein, B. (2011). The quality of government basic dataset made from the QoG standard dataset version 6apr11. The Quality of Government Institute, University of Gothenburg, http://www. qog.pol.gu. se.

Thompson, A. (2006). Coercion through IOs: The Security Council and the logic of information transmission. International Organization, 60(1):1.

Times, N. Y. (1994). Horror in Rwanda, shame in the U.N. http://www.nytimes.com/1994/ 05/03/opinion/horror-in-rwanda-shame-in-the-un.html.

Voeten, E. (2001). Outside options and the logic of Security Council action. American Political Science Review, 95(4):845-858.

Voeten, E. and Merdzanovic, A. (2013). United Nations general assembly voting data. Accessed online November 2013.

Wallensteen, P. (2011). Understanding conflict resolution: War, peace and the global system. Sage. 


\section{Figures}
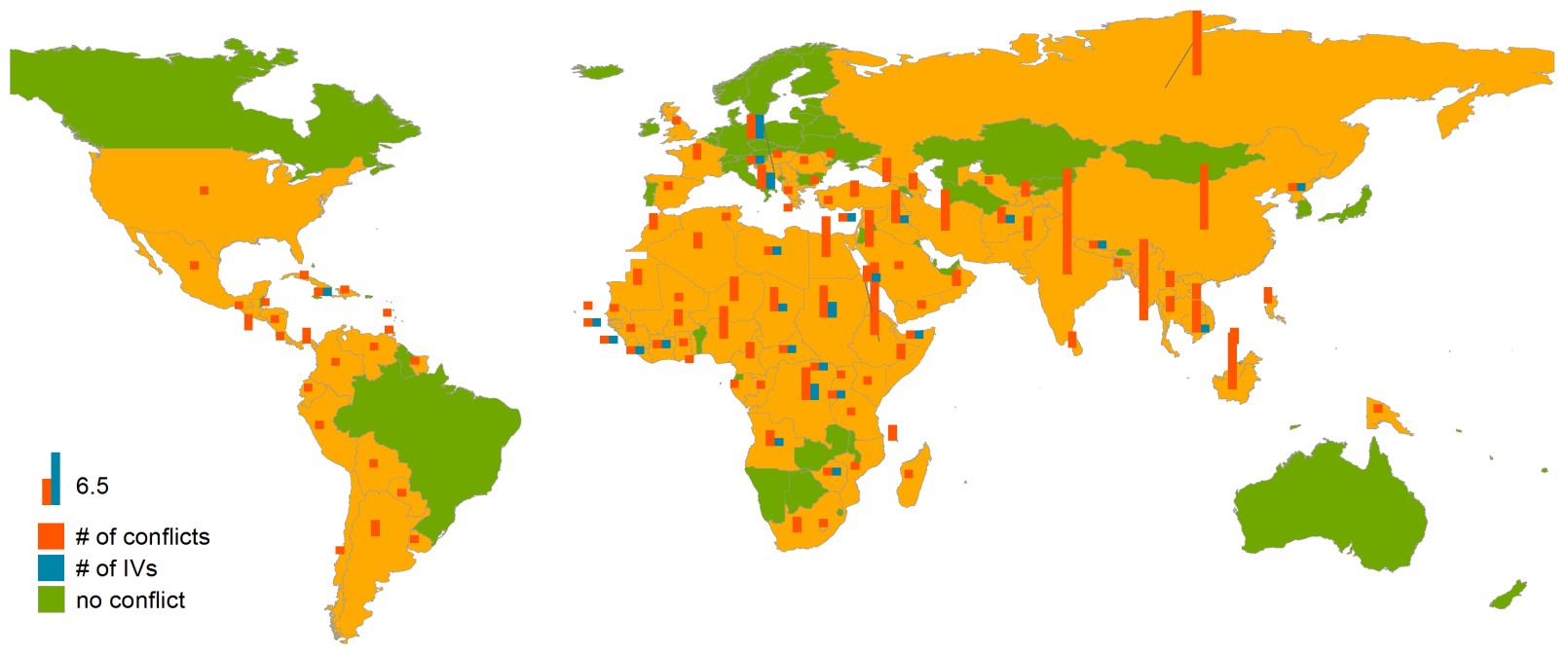

Figure 1: Conflicts and interventions
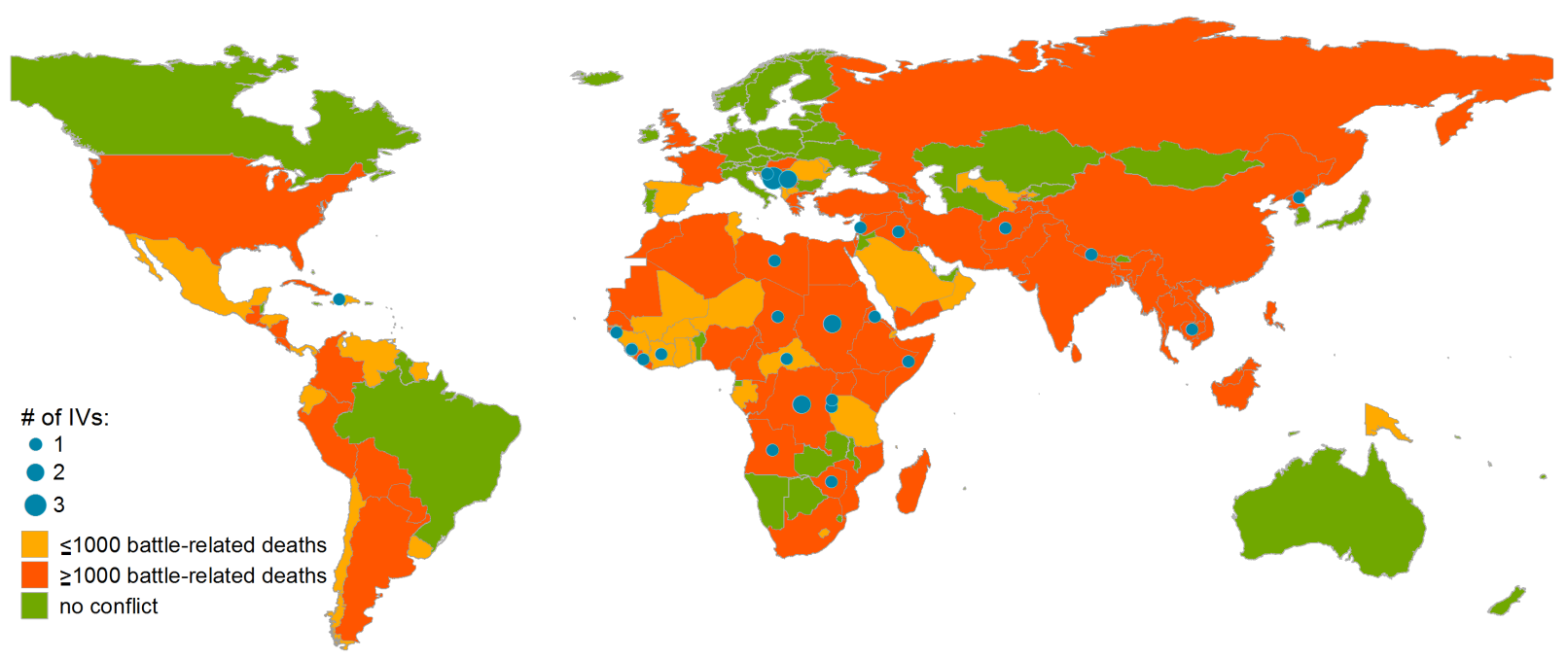

Figure 2: Interventions and intensity 


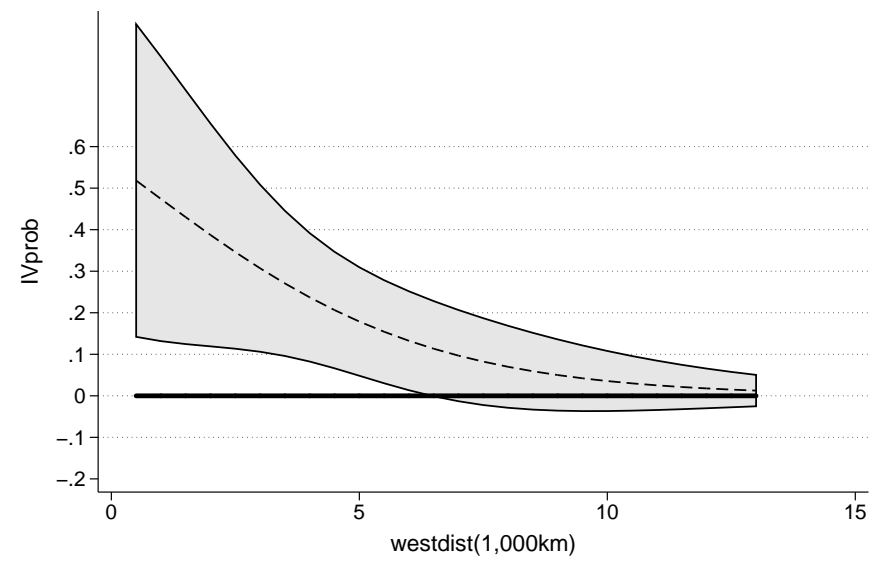

Figure 3: Predicted probability of UN military intervention in intense internal conflict, at means

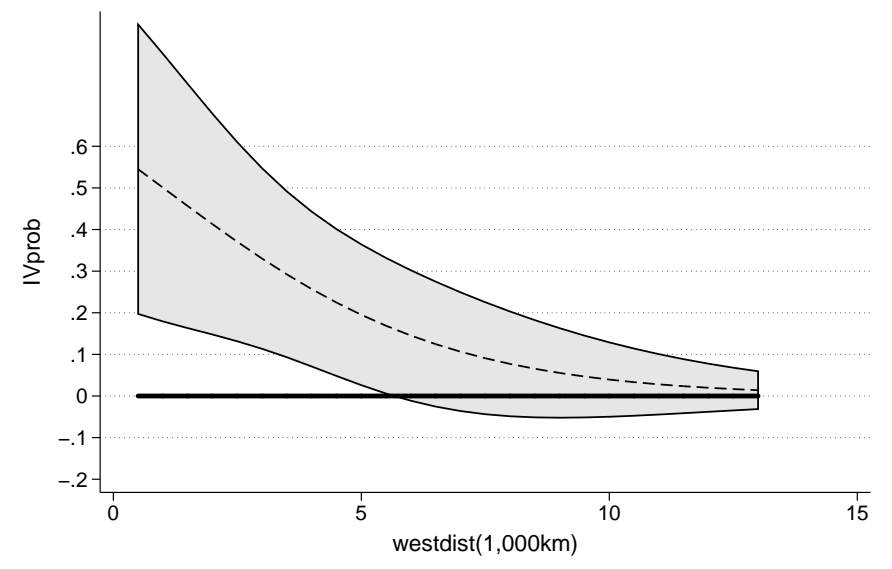

Figure 4: Predicted probability of UN military intervention in intense interstate conflict, at means 


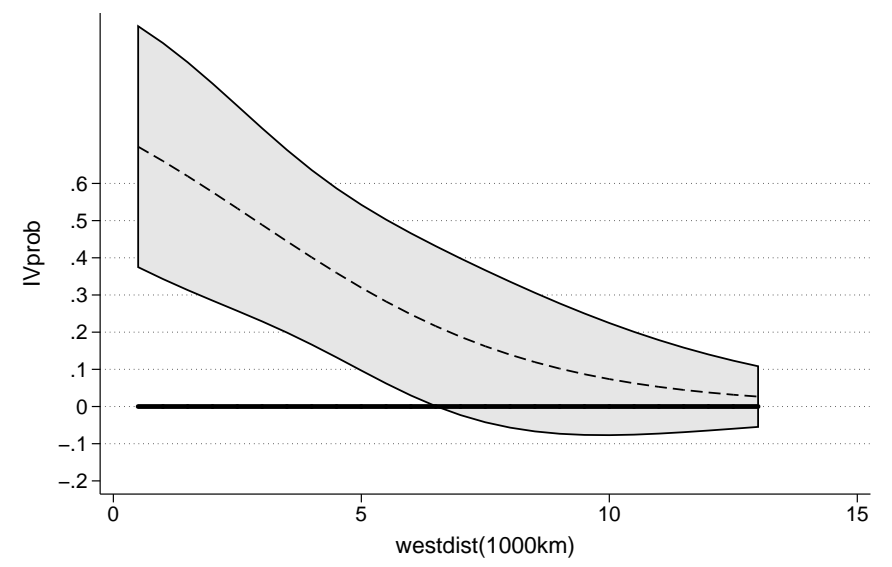

Figure 5: Predicted probability of UN military intervention in intense internationalized conflict, at means
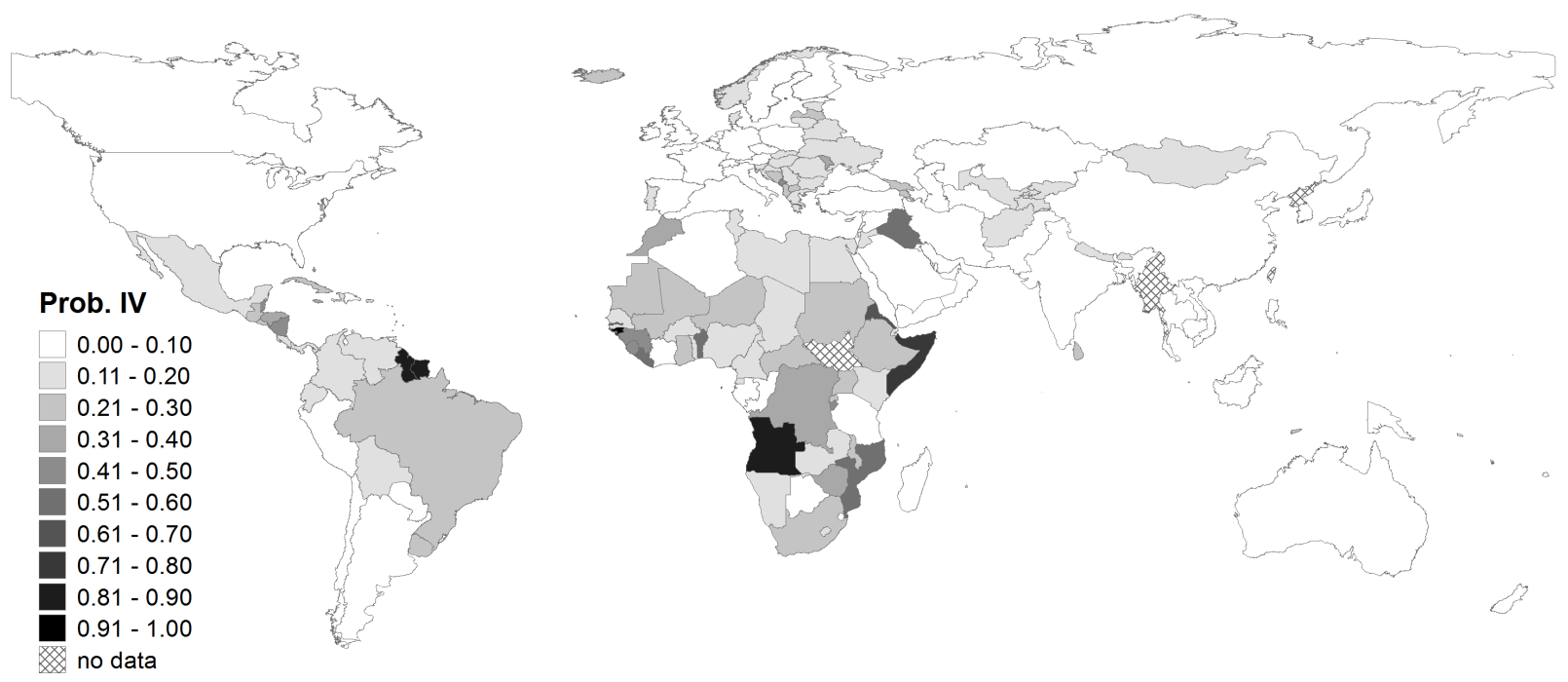

Figure 6: Predicted Probability of Intervention (using Table 1, Column 6) 


\section{Tables}

Table 1: Logit regression results, displaying marginal effects. Dependent variable is probability of military intervention by the UN $(I V)$.

\begin{tabular}{|c|c|c|c|c|c|c|}
\hline & $(1)$ & $(2)$ & $(3)$ & $(4)$ & $(5)$ & (6) \\
\hline \multicolumn{7}{|c|}{ Dependent variable: $I V$} \\
\hline chidist & $\begin{array}{c}0.002 \\
(0.012)\end{array}$ & & & & & \\
\hline fradist & & $\begin{array}{c}-0.035^{*} \\
(0.019)\end{array}$ & & & & \\
\hline rusdist & & & $\begin{array}{l}-0.028 \\
(0.021)\end{array}$ & & & \\
\hline ukdist & & & & $\begin{array}{c}-0.035^{*} \\
(0.018)\end{array}$ & & \\
\hline usdist & & & & & $\begin{array}{c}-0.040^{* * *} \\
(0.015)\end{array}$ & \\
\hline westdist & & & & & & $\begin{array}{c}-0.040^{* *} \\
(0.019)\end{array}$ \\
\hline eastdist & & & & & & $\begin{array}{l}-0.007 \\
(0.027)\end{array}$ \\
\hline intense & $\begin{array}{c}0.163^{* * *} \\
(0.058)\end{array}$ & $\begin{array}{c}0.150^{* *} \\
(0.059)\end{array}$ & $\begin{array}{c}0.157^{* * *} \\
(0.056)\end{array}$ & $\begin{array}{c}0.150^{* *} \\
(0.059)\end{array}$ & $\begin{array}{c}0.157^{* * *} \\
(0.056)\end{array}$ & $\begin{array}{c}0.141^{* *} \\
(0.058)\end{array}$ \\
\hline internal & $\begin{array}{l}-0.090 \\
(0.072)\end{array}$ & $\begin{array}{l}-0.089 \\
(0.071)\end{array}$ & $\begin{array}{l}-0.084 \\
(0.071)\end{array}$ & $\begin{array}{l}-0.090 \\
(0.071)\end{array}$ & $\begin{array}{l}-0.097 \\
(0.072)\end{array}$ & $\begin{array}{c}-0.087 \\
(0.072)\end{array}$ \\
\hline interstate & $\begin{array}{l}-0.057 \\
(0.086)\end{array}$ & $\begin{array}{l}-0.080 \\
(0.085)\end{array}$ & $\begin{array}{c}-0.076 \\
(0.084)\end{array}$ & $\begin{array}{l}-0.080 \\
(0.085)\end{array}$ & $\begin{array}{l}-0.084 \\
(0.088)\end{array}$ & $\begin{array}{c}-0.091 \\
(0.084)\end{array}$ \\
\hline $\operatorname{lnpop}$ & $\begin{array}{c}-0.043^{* *} \\
(0.022)\end{array}$ & $\begin{array}{c}-0.049^{* *} \\
(0.023)\end{array}$ & $\begin{array}{c}-0.051^{* *} \\
(0.023)\end{array}$ & $\begin{array}{c}-0.050^{* *} \\
(0.023)\end{array}$ & $\begin{array}{c}-0.059^{* *} \\
(0.026)\end{array}$ & $\begin{array}{c}-0.054^{* *} \\
(0.023)\end{array}$ \\
\hline $\operatorname{lng} d p$ & $\begin{array}{l}-0.057 \\
(0.044)\end{array}$ & $\begin{array}{c}-0.083^{* *} \\
(0.042)\end{array}$ & $\begin{array}{l}-0.057 \\
(0.039)\end{array}$ & $\begin{array}{c}-0.084^{* *} \\
(0.042)\end{array}$ & $\begin{array}{c}-0.085^{* *} \\
(0.041)\end{array}$ & $\begin{array}{c}-0.085^{* *} \\
(0.041)\end{array}$ \\
\hline lnopen & $\begin{array}{l}-0.023 \\
(0.039)\end{array}$ & $\begin{array}{l}-0.037 \\
(0.041)\end{array}$ & $\begin{array}{l}-0.031 \\
(0.039)\end{array}$ & $\begin{array}{l}-0.037 \\
(0.041)\end{array}$ & $\begin{array}{c}-0.043 \\
(0.040)\end{array}$ & $\begin{array}{c}-0.046 \\
(0.041)\end{array}$ \\
\hline africa & $\begin{array}{c}0.041 \\
(0.151)\end{array}$ & $\begin{array}{l}-0.151 \\
(0.184)\end{array}$ & $\begin{array}{c}-0.118 \\
(0.183)\end{array}$ & $\begin{array}{l}-0.122 \\
(0.174)\end{array}$ & $\begin{array}{c}0.247^{*} \\
(0.149)\end{array}$ & $\begin{array}{c}0.009 \\
(0.204)\end{array}$ \\
\hline asia & $\begin{array}{l}-0.081 \\
(0.190)\end{array}$ & $\begin{array}{l}-0.227 \\
(0.165)\end{array}$ & $\begin{array}{l}-0.315 \\
(0.213)\end{array}$ & $\begin{array}{c}-0.212 \\
(0.160)\end{array}$ & $\begin{array}{c}0.155 \\
(0.159)\end{array}$ & $\begin{array}{c}-0.080 \\
(0.280)\end{array}$ \\
\hline europe & $\begin{array}{c}0.043 \\
(0.151)\end{array}$ & $\begin{array}{l}-0.208 \\
(0.187)\end{array}$ & $\begin{array}{l}-0.208 \\
(0.215)\end{array}$ & $\begin{array}{c}-0.194 \\
(0.179)\end{array}$ & $\begin{array}{c}0.190 \\
(0.122)\end{array}$ & $\begin{array}{c}-0.077 \\
(0.255)\end{array}$ \\
\hline Colony fixed effects & yes & yes & yes & yes & yes & yes \\
\hline$N$ & 174 & 174 & 174 & 174 & 174 & 174 \\
\hline Log lik. & -72.14 & -70.18 & -71.29 & -70.14 & -69.45 & -69.11 \\
\hline Chi-squared & 37.25 & 41.63 & 40.61 & 41.71 & 41.41 & 44.11 \\
\hline
\end{tabular}

Robust standard errors in parentheses. ${ }^{*} p<0.10,{ }^{* *} p<0.05,{ }^{* * *} p<0.01$ 
Table 2: Political explanations. Logit regression results, displaying marginal effects. Dependent variable is probability of military intervention by the UN $(I V)$.

\begin{tabular}{|c|c|c|c|c|c|c|}
\hline & $(1)$ & $\begin{array}{c}\text { Only Cold } \\
\text { War Period } \\
(2)\end{array}$ & $\begin{array}{c}\text { Excl. } \\
\text { Europe } \\
(3)\end{array}$ & $\begin{array}{c}\text { Excl. Conflicts } \\
\text { in } 5 \mathrm{PMs} \\
(4)\end{array}$ & $(5)$ & (6) \\
\hline \multicolumn{7}{|c|}{ Dependent variable: $I V$} \\
\hline westdist & $\begin{array}{c}-0.036^{*} \\
(0.020)\end{array}$ & $\begin{array}{c}-0.056^{* *} \\
(0.026)\end{array}$ & $\begin{array}{c}-0.043^{* *} \\
(0.021)\end{array}$ & $\begin{array}{c}-0.049^{* *} \\
(0.022)\end{array}$ & $\begin{array}{c}-0.041^{* *} \\
(0.019)\end{array}$ & $\begin{array}{r}-0.050^{* * *} \\
(0.019)\end{array}$ \\
\hline eastdist & $\begin{array}{l}-0.010 \\
(0.025)\end{array}$ & $\begin{array}{c}0.000 \\
(0.037)\end{array}$ & $\begin{array}{c}-0.002 \\
(0.030)\end{array}$ & $\begin{array}{c}0.003 \\
(0.031)\end{array}$ & $\begin{array}{l}-0.007 \\
(0.025)\end{array}$ & $\begin{array}{c}0.003 \\
(0.029)\end{array}$ \\
\hline coldwar & $\begin{array}{c}-0.111^{*} \\
(0.065)\end{array}$ & & & & & \\
\hline ownint & & & & & $\begin{array}{c}0.207^{* *} \\
(0.090)\end{array}$ & \\
\hline polityIV & & & & & & $\begin{array}{c}-0.010^{*} \\
(0.006)\end{array}$ \\
\hline intense & $\begin{array}{c}0.165^{* * *} \\
(0.059)\end{array}$ & $\begin{array}{l}0.161^{* *} \\
(0.067)\end{array}$ & $\begin{array}{c}0.128^{* *} \\
(0.058)\end{array}$ & $\begin{array}{l}0.153^{* *} \\
(0.062)\end{array}$ & $\begin{array}{c}0.163^{* * *} \\
(0.059)\end{array}$ & $\begin{array}{l}0.092^{*} \\
(0.055)\end{array}$ \\
\hline internal & $\begin{array}{c}-0.071 \\
(0.070)\end{array}$ & $\begin{array}{l}-0.056 \\
(0.080)\end{array}$ & $\begin{array}{c}-0.073 \\
(0.073)\end{array}$ & $\begin{array}{l}-0.093 \\
(0.078)\end{array}$ & $\begin{array}{c}-0.023 \\
(0.083)\end{array}$ & $\begin{array}{l}-0.107 \\
(0.068)\end{array}$ \\
\hline interstate & $\begin{array}{c}-0.064 \\
(0.082)\end{array}$ & $\begin{array}{l}-0.039 \\
(0.096)\end{array}$ & $\begin{array}{c}-0.051 \\
(0.092)\end{array}$ & $\begin{array}{l}-0.062 \\
(0.097)\end{array}$ & $\begin{array}{c}-0.029 \\
(0.090)\end{array}$ & $\begin{array}{c}-0.076 \\
(0.081)\end{array}$ \\
\hline $\operatorname{lnpop}$ & $\begin{array}{c}-0.056^{* *} \\
(0.022)\end{array}$ & $\begin{array}{c}-0.059^{* *} \\
(0.025)\end{array}$ & $\begin{array}{c}-0.057^{* *} \\
(0.023)\end{array}$ & $\begin{array}{c}-0.040 \\
(0.025)\end{array}$ & $\begin{array}{c}-0.048^{* *} \\
(0.023)\end{array}$ & $\begin{array}{c}-0.077^{* * *} \\
(0.023)\end{array}$ \\
\hline $\operatorname{lng} d p$ & $\begin{array}{l}-0.079^{*} \\
(0.041)\end{array}$ & $\begin{array}{c}-0.105^{* *} \\
(0.053)\end{array}$ & $\begin{array}{c}-0.099^{* *} \\
(0.047)\end{array}$ & $\begin{array}{c}-0.084^{*} \\
(0.047)\end{array}$ & $\begin{array}{c}-0.091^{* *} \\
(0.041)\end{array}$ & $\begin{array}{c}-0.089^{* *} \\
(0.040)\end{array}$ \\
\hline lnopen & $\begin{array}{l}-0.065 \\
(0.043)\end{array}$ & $\begin{array}{l}-0.050 \\
(0.048)\end{array}$ & $\begin{array}{l}-0.062 \\
(0.044)\end{array}$ & $\begin{array}{l}-0.069 \\
(0.045)\end{array}$ & $\begin{array}{c}-0.038 \\
(0.041)\end{array}$ & $\begin{array}{l}-0.055 \\
(0.042)\end{array}$ \\
\hline africa & $\begin{array}{c}-0.011 \\
(0.193)\end{array}$ & $\begin{array}{c}0.026 \\
(0.256)\end{array}$ & $\begin{array}{c}0.031 \\
(0.223)\end{array}$ & $\begin{array}{c}0.075 \\
(0.233)\end{array}$ & $\begin{array}{c}0.006 \\
(0.191)\end{array}$ & $\begin{array}{c}-0.015 \\
(0.216)\end{array}$ \\
\hline asia & $\begin{array}{c}-0.130 \\
(0.257)\end{array}$ & $\begin{array}{c}0.022 \\
(0.377)\end{array}$ & $\begin{array}{l}-0.030 \\
(0.307)\end{array}$ & $\begin{array}{c}0.020 \\
(0.326)\end{array}$ & $\begin{array}{l}-0.110 \\
(0.260)\end{array}$ & $\begin{array}{l}-0.008 \\
(0.308)\end{array}$ \\
\hline europe & $\begin{array}{l}-0.129 \\
(0.235)\end{array}$ & $\begin{array}{l}-0.110 \\
(0.353)\end{array}$ & & $\begin{array}{c}0.041 \\
(0.303)\end{array}$ & $\begin{array}{c}-0.073 \\
(0.233)\end{array}$ & $\begin{array}{c}-0.099 \\
(0.271)\end{array}$ \\
\hline Colony fixed effects & yes & yes & yes & yes & yes & yes \\
\hline$N$ & 174 & 132 & 154 & 160 & 174 & 164 \\
\hline Log lik. & -67.94 & -48.12 & -59.14 & -67.34 & -67.24 & -57.95 \\
\hline Chi-squared & 43.51 & 38.79 & 40.57 & 40.11 & 42.73 & 42.50 \\
\hline
\end{tabular}

Robust standard errors in parentheses. ${ }^{*} p<0.10,{ }^{* *} p<0.05,{ }^{* * *} p<0.01$ 
Table 3: Political explanations continued, considering the affinity to UN voting. Logit regression results, displaying marginal effects. Dependent variable is probability of military intervention by the UN $(I V)$.

\begin{tabular}{|c|c|c|c|c|c|c|}
\hline & (1) & $(2)$ & $(3)$ & (4) & $(5)$ & $(6)$ \\
\hline \multicolumn{7}{|c|}{ Dependent variable: $I V$} \\
\hline westdist & $\begin{array}{c}-0.051^{* *} \\
(0.026)\end{array}$ & $\begin{array}{c}-0.059^{* * *} \\
(0.021)\end{array}$ & $\begin{array}{c}-0.032^{*} \\
(0.019)\end{array}$ & $\begin{array}{c}-0.059^{* * *} \\
(0.021)\end{array}$ & $\begin{array}{c}-0.057^{* * *} \\
(0.020)\end{array}$ & $\begin{array}{c}-0.059^{* * *} \\
(0.023)\end{array}$ \\
\hline eastdist & $\begin{array}{c}0.046 \\
(0.032)\end{array}$ & $\begin{array}{c}0.026 \\
(0.032)\end{array}$ & $\begin{array}{c}0.027 \\
(0.037)\end{array}$ & $\begin{array}{c}0.027 \\
(0.032)\end{array}$ & $\begin{array}{c}0.025 \\
(0.032)\end{array}$ & $\begin{array}{c}0.040 \\
(0.032)\end{array}$ \\
\hline affchina & $\begin{array}{l}-0.150 \\
(0.419)\end{array}$ & & & & & \\
\hline afffrance & & $\begin{array}{c}-0.048 \\
(0.322)\end{array}$ & & & & \\
\hline affrussia & & & $\begin{array}{c}0.273 \\
(0.213)\end{array}$ & & & \\
\hline$a f f u k$ & & & & $\begin{array}{c}-0.067 \\
(0.305)\end{array}$ & & \\
\hline affus & & & & & $\begin{array}{c}-0.143 \\
(0.188)\end{array}$ & \\
\hline affwest & & & & & & $\begin{array}{c}0.013 \\
(0.363)\end{array}$ \\
\hline affeast & & & & & & $\begin{array}{c}-0.079 \\
(0.204)\end{array}$ \\
\hline Control variables ${ }^{a}$ & yes & yes & yes & yes & yes & yes \\
\hline Colony fixed effects & yes & yes & yes & yes & yes & yes \\
\hline$N$ & 112 & 150 & 131 & 150 & 149 & 140 \\
\hline Log lik. & -34.93 & -57.89 & -43.45 & -57.88 & -57.48 & -51.42 \\
\hline Chi-squared & 31.47 & 38.17 & 233.11 & 37.88 & 36.88 & 39.74 \\
\hline
\end{tabular}

Robust standard errors in parentheses. ${ }^{*} p<0.10,{ }^{* *} p<0.05,{ }^{* * *} p<0.01$

${ }^{a}$ Incorporates intense, internal, interstate, lnpop, lngdp, lnopen,

africa, asia, and europe. 
Table 4: Economic explanations. Logit regression results, displaying marginal effects. Dependent variable is probability of military intervention by the UN $(I V)$.

\begin{tabular}{|c|c|c|c|c|c|c|}
\hline & (1) & $(2)$ & (3) & $(4)$ & $(5)$ & (6) \\
\hline \multicolumn{7}{|c|}{ Dependent variable: $I V$} \\
\hline westdist & $\begin{array}{c}-0.038^{* *} \\
(0.019)\end{array}$ & $\begin{array}{c}-0.039^{* *} \\
(0.020)\end{array}$ & $\begin{array}{c}-0.044^{* *} \\
(0.020)\end{array}$ & $\begin{array}{c}-0.045^{* *} \\
(0.022)\end{array}$ & $\begin{array}{c}-0.037^{*} \\
(0.019)\end{array}$ & $\begin{array}{c}-0.043^{* *} \\
(0.021)\end{array}$ \\
\hline eastdist & $\begin{array}{c}0.006 \\
(0.015)\end{array}$ & $\begin{array}{c}0.009 \\
(0.016)\end{array}$ & $\begin{array}{c}0.014 \\
(0.016)\end{array}$ & $\begin{array}{c}0.014 \\
(0.015)\end{array}$ & $\begin{array}{l}-0.003 \\
(0.013)\end{array}$ & $\begin{array}{c}0.018 \\
(0.028)\end{array}$ \\
\hline lnexportstous & $\begin{array}{c}0.011 \\
(0.020)\end{array}$ & & & & & \\
\hline lnimportsfromus & & $\begin{array}{c}0.005 \\
(0.025)\end{array}$ & & & & \\
\hline lnexportstowest & & & $\begin{array}{c}-0.036 \\
(0.026)\end{array}$ & & & \\
\hline lnimports fromwest & & & & $\begin{array}{l}-0.056 \\
(0.036)\end{array}$ & & \\
\hline lntotalaid & & & & & $\begin{array}{c}0.036^{*} \\
(0.020)\end{array}$ & \\
\hline lnaidus & & & & & & $\begin{array}{c}-0.026 \\
(0.024)\end{array}$ \\
\hline Control variables $^{a}$ & yes & yes & yes & yes & yes & yes \\
\hline Colony fixed effects & yes & yes & yes & yes & yes & yes \\
\hline$N$ & 158 & 158 & 154 & 154 & 145 & 118 \\
\hline Log lik. & -57.45 & -57.59 & -56.18 & -55.99 & -54.40 & -46.22 \\
\hline Chi-squared & 43.71 & 42.17 & 39.12 & 42.33 & 38.73 & 32.68 \\
\hline
\end{tabular}

Robust standard errors in parentheses. ${ }^{*} p<0.10,{ }^{* *} p<0.05,{ }^{* * *} p<0.01$.

${ }^{a}$ Incorporates intense, internal, interstate, lnpop, lngdp, lnopen,

africa, and asia. europe omitted because it predicts failure perfectly. 
Table 5: Economic explanations continued, considering the geographical distance to major oil suppliers. Logit regression results, displaying marginal effects. Dependent variable is probability of military intervention by the UN $(I V)$.

\begin{tabular}{|c|c|c|c|c|c|c|}
\hline & (1) & $(2)$ & (3) & (4) & (5) & (6) \\
\hline \multicolumn{7}{|c|}{ Dependent variable: $I V$} \\
\hline westdist & $\begin{array}{c}-0.044^{* * *} \\
(0.017)\end{array}$ & $\begin{array}{c}-0.045^{* * *} \\
(0.017)\end{array}$ & $\begin{array}{c}-0.042^{* *} \\
(0.017)\end{array}$ & $\begin{array}{c}-0.043^{* * *} \\
(0.017)\end{array}$ & $\begin{array}{c}-0.103^{* *} \\
(0.052)\end{array}$ & $\begin{array}{c}-0.045^{* *} \\
(0.018)\end{array}$ \\
\hline eastdist & $\begin{array}{l}-0.021 \\
(0.029)\end{array}$ & $\begin{array}{l}-0.020 \\
(0.031)\end{array}$ & $\begin{array}{c}-0.023 \\
(0.034)\end{array}$ & $\begin{array}{l}-0.021 \\
(0.030)\end{array}$ & $\begin{array}{c}0.044 \\
(0.046)\end{array}$ & $\begin{array}{c}-0.014 \\
(0.029)\end{array}$ \\
\hline saudidist & $\begin{array}{c}0.019 \\
(0.024)\end{array}$ & & & & & \\
\hline iraqdist & & $\begin{array}{c}0.017 \\
(0.026)\end{array}$ & & & & \\
\hline irandist & & & $\begin{array}{c}0.019 \\
(0.029)\end{array}$ & & & \\
\hline kuwaitdist & & & & $\begin{array}{c}0.017 \\
(0.024)\end{array}$ & & \\
\hline venezueladist & & & & & $\begin{array}{c}0.052 \\
(0.039)\end{array}$ & \\
\hline isrdist & & & & & & $\begin{array}{c}0.011 \\
(0.025)\end{array}$ \\
\hline Control variables $^{a}$ & yes & yes & yes & yes & yes & yes \\
\hline Colony fixed effects & yes & yes & yes & yes & yes & yes \\
\hline$N$ & 174 & 174 & 174 & 174 & 174 & 174 \\
\hline Log lik. & -68.79 & -68.89 & -68.89 & -68.86 & -68.32 & -69.02 \\
\hline Chi-squared & 43.66 & 44.13 & 44.23 & 43.97 & 45.97 & 44.16 \\
\hline
\end{tabular}

Robust standard errors in parentheses. ${ }^{*} p<0.10,{ }^{* *} p<0.05,{ }^{* * *} p<0.01$

${ }^{a}$ Incorporates intense, internal, interstate, lnpop, lngdp, lnopen,

africa, asia, and europe. 
Table 6: Logit regression results, displaying marginal effects. Dependent variable is probability of any form of intervention by the UN (anyIV), including sanctions, embargoes, and observer missions.

\begin{tabular}{|c|c|c|c|c|c|c|}
\hline & $(1)$ & $(2)$ & $(3)$ & $(4)$ & $(5)$ & (6) \\
\hline \multicolumn{7}{|c|}{ Dependent variable: anyIV } \\
\hline chidist & $\begin{array}{l}-0.004 \\
(0.011)\end{array}$ & & & & & \\
\hline fradist & & $\begin{array}{l}-0.030 \\
(0.019)\end{array}$ & & & & \\
\hline rusdist & & & $\begin{array}{l}-0.020 \\
(0.022)\end{array}$ & & & \\
\hline ukdist & & & & $\begin{array}{l}-0.028 \\
(0.019)\end{array}$ & & \\
\hline usdist & & & & & $\begin{array}{l}-0.017 \\
(0.018)\end{array}$ & \\
\hline westdist & & & & & & $\begin{array}{c}-0.035^{*} \\
(0.021)\end{array}$ \\
\hline eastdist & & & & & & $\begin{array}{c}0.014 \\
(0.032)\end{array}$ \\
\hline intense & $\begin{array}{c}0.304^{* * *} \\
(0.050)\end{array}$ & $\begin{array}{c}0.279^{* * *} \\
(0.051)\end{array}$ & $\begin{array}{c}0.292^{* * *} \\
(0.050)\end{array}$ & $\begin{array}{c}0.280^{* * *} \\
(0.051)\end{array}$ & $\begin{array}{c}0.293^{* * *} \\
(0.049)\end{array}$ & $\begin{array}{r}0.274^{* * *} \\
(0.050)\end{array}$ \\
\hline internal & $\begin{array}{c}-0.146^{* *} \\
(0.066)\end{array}$ & $\begin{array}{c}-0.153^{* *} \\
(0.067)\end{array}$ & $\begin{array}{c}-0.144^{* *} \\
(0.066)\end{array}$ & $\begin{array}{c}-0.153^{* *} \\
(0.067)\end{array}$ & $\begin{array}{c}-0.155^{* *} \\
(0.068)\end{array}$ & $\begin{array}{r}-0.160^{* *} \\
(0.067)\end{array}$ \\
\hline interstate & $\begin{array}{c}0.004 \\
(0.085)\end{array}$ & $\begin{array}{l}-0.025 \\
(0.090)\end{array}$ & $\begin{array}{l}-0.011 \\
(0.086)\end{array}$ & $\begin{array}{l}-0.024 \\
(0.090)\end{array}$ & $\begin{array}{l}-0.013 \\
(0.089)\end{array}$ & $\begin{array}{l}-0.026 \\
(0.092)\end{array}$ \\
\hline lnpop & $\begin{array}{c}-0.053^{* *} \\
(0.022)\end{array}$ & $\begin{array}{c}-0.055^{* *} \\
(0.023)\end{array}$ & $\begin{array}{c}-0.058^{* *} \\
(0.023)\end{array}$ & $\begin{array}{c}-0.056^{* *} \\
(0.023)\end{array}$ & $\begin{array}{r}-0.057^{* *} \\
(0.024)\end{array}$ & $\begin{array}{r}-0.053^{* *} \\
(0.024)\end{array}$ \\
\hline $\operatorname{lng} d p$ & $\begin{array}{c}0.037 \\
(0.037)\end{array}$ & $\begin{array}{c}0.003 \\
(0.043)\end{array}$ & $\begin{array}{c}0.030 \\
(0.035)\end{array}$ & $\begin{array}{c}0.005 \\
(0.043)\end{array}$ & $\begin{array}{c}0.018 \\
(0.042)\end{array}$ & $\begin{array}{c}0.002 \\
(0.044)\end{array}$ \\
\hline lnopen & $\begin{array}{l}-0.013 \\
(0.043)\end{array}$ & $\begin{array}{l}-0.018 \\
(0.045)\end{array}$ & $\begin{array}{l}-0.016 \\
(0.044)\end{array}$ & $\begin{array}{l}-0.018 \\
(0.045)\end{array}$ & $\begin{array}{l}-0.018 \\
(0.044)\end{array}$ & $\begin{array}{c}-0.023 \\
(0.045)\end{array}$ \\
\hline africa & $\begin{array}{c}0.010 \\
(0.138)\end{array}$ & $\begin{array}{l}-0.133 \\
(0.180)\end{array}$ & $\begin{array}{l}-0.075 \\
(0.179)\end{array}$ & $\begin{array}{l}-0.096 \\
(0.168)\end{array}$ & $\begin{array}{c}0.112 \\
(0.149)\end{array}$ & $\begin{array}{c}0.100 \\
(0.209)\end{array}$ \\
\hline asia & $\begin{array}{l}-0.106 \\
(0.155)\end{array}$ & $\begin{array}{l}-0.170 \\
(0.147)\end{array}$ & $\begin{array}{l}-0.208 \\
(0.204)\end{array}$ & $\begin{array}{l}-0.148 \\
(0.141)\end{array}$ & $\begin{array}{c}0.044 \\
(0.152)\end{array}$ & $\begin{array}{c}0.109 \\
(0.304)\end{array}$ \\
\hline europe & $\begin{array}{c}0.088 \\
(0.142)\end{array}$ & $\begin{array}{l}-0.081 \\
(0.173)\end{array}$ & $\begin{array}{l}-0.040 \\
(0.213)\end{array}$ & $\begin{array}{l}-0.054 \\
(0.165)\end{array}$ & $\begin{array}{c}0.188 \\
(0.127)\end{array}$ & $\begin{array}{c}0.186 \\
(0.284)\end{array}$ \\
\hline Colony fixed effects & yes & yes & yes & yes & yes & yes \\
\hline$N$ & 174 & 174 & 174 & 174 & 174 & 174 \\
\hline Log lik. & -77.75 & -76.47 & -77.41 & -76.65 & -77.34 & -76.27 \\
\hline Chi-squared & 39.81 & 46.08 & 40.06 & 45.41 & 41.77 & 48.77 \\
\hline
\end{tabular}

Robust standard errors in parentheses. ${ }^{*} p<0.10,{ }^{* *} p<0.05,{ }^{* * *} p<0.01$ 
Table 7: Logit regression results, displaying marginal effects. Dependent variable is probability of non-military form of intervention by the UN (nonmilitaryIV). These include sanctions, embargoes, and observer missions.

\begin{tabular}{|c|c|c|c|c|c|c|}
\hline & $(1)$ & $(2)$ & (3) & $(4)$ & $(5)$ & (6) \\
\hline \multicolumn{7}{|c|}{ Dependent variable: nonmilitaryIV } \\
\hline chidist & $\begin{array}{l}-0.005 \\
(0.009)\end{array}$ & & & & & \\
\hline fradist & & $\begin{array}{l}-0.000 \\
(0.013)\end{array}$ & & & & \\
\hline rusdist & & & $\begin{array}{c}0.011 \\
(0.018)\end{array}$ & & & \\
\hline ukdist & & & & $\begin{array}{c}0.003 \\
(0.014)\end{array}$ & & \\
\hline usdist & & & & & $\begin{array}{c}0.021 \\
(0.019)\end{array}$ & \\
\hline westdist & & & & & & $\begin{array}{l}-0.004 \\
(0.017)\end{array}$ \\
\hline eastdist & & & & & & $\begin{array}{c}0.030 \\
(0.028)\end{array}$ \\
\hline intense & $\begin{array}{c}0.175^{* * *} \\
(0.059)\end{array}$ & $\begin{array}{c}0.167^{* * *} \\
(0.058)\end{array}$ & $\begin{array}{c}0.171^{* * *} \\
(0.059)\end{array}$ & $\begin{array}{c}0.170^{* * *} \\
(0.058)\end{array}$ & $\begin{array}{c}0.180^{* * *} \\
(0.056)\end{array}$ & $\begin{array}{r}0.164^{* * *} \\
(0.050)\end{array}$ \\
\hline internal & $\begin{array}{c}-0.131^{* *} \\
(0.058)\end{array}$ & $\begin{array}{c}-0.137^{* *} \\
(0.055)\end{array}$ & $\begin{array}{c}-0.142^{* *} \\
(0.059)\end{array}$ & $\begin{array}{c}-0.135^{* *} \\
(0.055)\end{array}$ & $\begin{array}{c}-0.128^{* *} \\
(0.053)\end{array}$ & $\begin{array}{c}-0.161^{* *} \\
(0.068)\end{array}$ \\
\hline interstate & $\begin{array}{c}0.024 \\
(0.070)\end{array}$ & $\begin{array}{c}0.017 \\
(0.074)\end{array}$ & $\begin{array}{c}0.021 \\
(0.070)\end{array}$ & $\begin{array}{c}0.022 \\
(0.074)\end{array}$ & $\begin{array}{c}0.045 \\
(0.071)\end{array}$ & $\begin{array}{c}0.008 \\
(0.096)\end{array}$ \\
\hline $\operatorname{lnpop}$ & $\begin{array}{l}-0.021 \\
(0.015)\end{array}$ & $\begin{array}{l}-0.016 \\
(0.015)\end{array}$ & $\begin{array}{l}-0.012 \\
(0.015)\end{array}$ & $\begin{array}{l}-0.016 \\
(0.015)\end{array}$ & $\begin{array}{l}-0.008 \\
(0.015)\end{array}$ & $\begin{array}{l}-0.006 \\
(0.016)\end{array}$ \\
\hline $\operatorname{lng} d p$ & $\begin{array}{l}0.054^{*} \\
(0.028)\end{array}$ & $\begin{array}{c}0.052 \\
(0.037)\end{array}$ & $\begin{array}{c}0.057^{* *} \\
(0.029)\end{array}$ & $\begin{array}{c}0.056 \\
(0.036)\end{array}$ & $\begin{array}{c}0.070^{* *} \\
(0.032)\end{array}$ & $\begin{array}{c}0.055 \\
(0.034)\end{array}$ \\
\hline lnopen & $\begin{array}{c}0.015 \\
(0.032)\end{array}$ & $\begin{array}{c}0.023 \\
(0.035)\end{array}$ & $\begin{array}{c}0.026 \\
(0.035)\end{array}$ & $\begin{array}{c}0.024 \\
(0.035)\end{array}$ & $\begin{array}{c}0.033 \\
(0.034)\end{array}$ & $\begin{array}{c}0.029 \\
(0.037)\end{array}$ \\
\hline africa & $\begin{array}{l}-0.042 \\
(0.098)\end{array}$ & $\begin{array}{l}-0.019 \\
(0.147)\end{array}$ & $\begin{array}{c}0.035 \\
(0.136)\end{array}$ & $\begin{array}{c}-0.004 \\
(0.133)\end{array}$ & $\begin{array}{l}-0.125 \\
(0.120)\end{array}$ & $\begin{array}{c}0.120 \\
(0.147)\end{array}$ \\
\hline asia & $\begin{array}{l}-0.032 \\
(0.103)\end{array}$ & $\begin{array}{c}0.023 \\
(0.100)\end{array}$ & $\begin{array}{c}0.108 \\
(0.167)\end{array}$ & $\begin{array}{c}0.034 \\
(0.094)\end{array}$ & $\begin{array}{c}-0.101 \\
(0.125)\end{array}$ & $\begin{array}{c}0.289 \\
(0.270)\end{array}$ \\
\hline europe & $\begin{array}{c}0.078 \\
(0.097)\end{array}$ & $\begin{array}{c}0.116 \\
(0.120)\end{array}$ & $\begin{array}{c}0.210 \\
(0.180)\end{array}$ & $\begin{array}{c}0.139 \\
(0.118)\end{array}$ & $\begin{array}{c}0.050 \\
(0.090)\end{array}$ & $\begin{array}{c}0.372 \\
(0.249)\end{array}$ \\
\hline Colony fixed effects ${ }^{a}$ & yes & yes & yes & yes & yes & yes \\
\hline$N$ & 134 & 134 & 134 & 134 & 134 & 134 \\
\hline Log lik. & -31.59 & -31.71 & -31.53 & -31.69 & -30.74 & -30.70 \\
\hline Chi-squared & 44.38 & 43.74 & 46.80 & 41.74 & 39.95 & 47.89 \\
\hline
\end{tabular}

Robust standard errors in parentheses. ${ }^{*} p<0.10,{ }^{* *} p<0.05,{ }^{* * *} p<0.01$

${ }^{a}$ The dummy for Portuguese colonies is excluded as it predicts failure perfectly. 
Table 8: Classic non-spatial Probit and spatial diagnostics. Dependent variable is probability to intervene (IV spatial), replicating table 1. Displaying marginal effects.

\begin{tabular}{|c|c|c|c|c|c|c|}
\hline & $(1)$ & $(2)$ & $(3)$ & $(4)$ & $(5)$ & $(6)$ \\
\hline chidist & $\begin{array}{c}-0.006 \\
(0.017)\end{array}$ & & & & & \\
\hline fradist & & $\begin{array}{c}-0.062^{* *} \\
(0.028)\end{array}$ & & & & \\
\hline rusdist & & & $\begin{array}{c}-0.046 \\
(0.032)\end{array}$ & & & \\
\hline ukdist & & & & $\begin{array}{c}-0.062^{* *} \\
(0.028)\end{array}$ & & \\
\hline usdist & & & & & $\begin{array}{c}-0.049^{* *} \\
(0.025)\end{array}$ & \\
\hline westdist & & & & & & $\begin{array}{c}-0.073^{* *} \\
(0.032)\end{array}$ \\
\hline eastdist & & & & & & $\begin{array}{l}-0.005 \\
(0.042)\end{array}$ \\
\hline maxintense & $\begin{array}{c}0.296^{* * *} \\
(0.103)\end{array}$ & $\begin{array}{c}0.259^{* * *} \\
(0.098)\end{array}$ & $\begin{array}{c}0.264^{* * *} \\
(0.101)\end{array}$ & $\begin{array}{c}0.261^{* * *} \\
(0.098)\end{array}$ & $\begin{array}{c}0.283^{* * *} \\
(0.099)\end{array}$ & $\begin{array}{l}0.236^{* *} \\
(0.097)\end{array}$ \\
\hline ninternal & $\begin{array}{c}0.019 \\
(0.041)\end{array}$ & $\begin{array}{c}0.018 \\
(0.041)\end{array}$ & $\begin{array}{l}0.014 \\
(0.04)\end{array}$ & $\begin{array}{c}0.018 \\
(0.041)\end{array}$ & $\begin{array}{c}0.021 \\
(0.041)\end{array}$ & $\begin{array}{c}0.02 \\
(0.041)\end{array}$ \\
\hline ninterstate & $\begin{array}{l}0.059 \\
(0.06)\end{array}$ & $\begin{array}{c}0.045 \\
(0.059)\end{array}$ & $\begin{array}{l}0.038 \\
(0.06)\end{array}$ & $\begin{array}{c}0.045 \\
(0.059)\end{array}$ & $\begin{array}{c}0.043 \\
(0.058)\end{array}$ & $\begin{array}{c}0.04 \\
(0.06)\end{array}$ \\
\hline lnpopavg & $\begin{array}{c}-0.059 \\
(0.04)\end{array}$ & $\begin{array}{c}-0.063 \\
(0.04)\end{array}$ & $\begin{array}{l}-0.062 \\
(0.039)\end{array}$ & $\begin{array}{c}-0.064 \\
(0.04)\end{array}$ & $\begin{array}{c}-0.078^{*} \\
(0.041)\end{array}$ & $\begin{array}{l}-0.07^{*} \\
(0.04)\end{array}$ \\
\hline lngdpavg & $\begin{array}{c}-0.114^{*} \\
(0.063)\end{array}$ & $\begin{array}{c}-0.176^{* * *} \\
(0.064)\end{array}$ & $\begin{array}{c}-0.123^{* *} \\
(0.058)\end{array}$ & $\begin{array}{c}-0.175^{* * *} \\
(0.063)\end{array}$ & $\begin{array}{c}-0.155^{* *} \\
(0.061)\end{array}$ & $\begin{array}{c}-0.176^{* * *} \\
(0.061)\end{array}$ \\
\hline lnopenavg & $\begin{array}{c}-0.004 \\
(0.068)\end{array}$ & $\begin{array}{r}-0.015 \\
(0.07)\end{array}$ & $\begin{array}{l}-0.008 \\
(0.068)\end{array}$ & $\begin{array}{l}-0.015 \\
(0.069)\end{array}$ & $\begin{array}{l}-0.026 \\
(0.068)\end{array}$ & $\begin{array}{r}-0.033 \\
(0.07)\end{array}$ \\
\hline africa & $\begin{array}{l}-0.049 \\
(0.169)\end{array}$ & $\begin{array}{c}-0.31 \\
(0.197)\end{array}$ & $\begin{array}{c}-0.231 \\
(0.204)\end{array}$ & $\begin{array}{c}-0.253 \\
(0.179)\end{array}$ & $\begin{array}{c}0.249 \\
(0.202)\end{array}$ & $\begin{array}{c}0.035 \\
(0.267)\end{array}$ \\
\hline asia & $\begin{array}{c}-0.234 \\
(0.253)\end{array}$ & $\begin{array}{c}-0.368^{*} \\
(0.191)\end{array}$ & $\begin{array}{c}-0.501^{*} \\
(0.285)\end{array}$ & $\begin{array}{c}-0.334^{*} \\
(0.182)\end{array}$ & $\begin{array}{c}0.175 \\
(0.236)\end{array}$ & $\begin{array}{l}-0.026 \\
(0.422)\end{array}$ \\
\hline europe & $\begin{array}{c}0.02 \\
-0.227\end{array}$ & $\begin{array}{c}-0.321 \\
(0.23)\end{array}$ & $\begin{array}{c}-0.297 \\
(0.298)\end{array}$ & $\begin{array}{l}-0.287 \\
(0.218)\end{array}$ & $\begin{array}{c}0.287 \\
(0.191)\end{array}$ & $\begin{array}{c}-0.024 \\
(0.379)\end{array}$ \\
\hline Colony fixed effects & yes & yes & yes & yes & yes & yes \\
\hline$N$ & 94 & 94 & 94 & 94 & 94 & 94 \\
\hline \multicolumn{7}{|c|}{ Diagnostic for spatial dependence } \\
\hline Kelejian-Prucha $M I$ test & $1.835^{*}$ & 1.193 & 1.584 & 1.246 & $1.798^{*}$ & 1.193 \\
\hline
\end{tabular}

Standard errors in parentheses. ${ }^{*} p<0.10,{ }^{* *} p<0.05,{ }^{* * *} p<0.01$ 
Table 9: Additional robustness checks from logit regressions, displaying marginal effects. Dependent variable is probability of military intervention by the UN $(I V)$.

\begin{tabular}{|c|c|c|c|c|c|c|c|}
\hline & (1) & $(2)$ & $(3)$ & $(4)$ & $(5)$ & (6) & (7) \\
\hline \multicolumn{8}{|c|}{ Dependent variable: anyIV } \\
\hline westdist & $\begin{array}{c}-0.041^{* *} \\
(0.019)\end{array}$ & $\begin{array}{c}-0.038^{* *} \\
(0.019)\end{array}$ & $\begin{array}{c}-0.036^{* *} \\
(0.018)\end{array}$ & $\begin{array}{c}-0.040^{* *} \\
(0.019)\end{array}$ & $\begin{array}{c}-0.036^{*} \\
(0.019)\end{array}$ & $\begin{array}{c}-0.039^{* *} \\
(0.019)\end{array}$ & $\begin{array}{c}-0.042^{* *} \\
(0.021)\end{array}$ \\
\hline eastdist & $\begin{array}{c}0.004 \\
(0.029)\end{array}$ & $\begin{array}{l}-0.008 \\
(0.026)\end{array}$ & $\begin{array}{l}-0.009 \\
(0.024)\end{array}$ & $\begin{array}{c}-0.007 \\
(0.027)\end{array}$ & $\begin{array}{c}-0.009 \\
(0.025)\end{array}$ & $\begin{array}{l}-0.008 \\
(0.027)\end{array}$ & $\begin{array}{l}-0.010 \\
(0.033)\end{array}$ \\
\hline $\operatorname{cinc}$ & $\begin{array}{l}-5.167 \\
(3.502)\end{array}$ & & & & & & \\
\hline year & & $\begin{array}{c}0.002 \\
(0.003)\end{array}$ & & & & & \\
\hline currentivs & & & $\begin{array}{l}0.008^{*} \\
(0.005)\end{array}$ & & & & \\
\hline ivprev & & & $\begin{array}{c}0.083 \\
(0.087)\end{array}$ & & & & \\
\hline unmember & & & & $\begin{array}{c}0.008 \\
(0.152)\end{array}$ & & & \\
\hline member & & & & & $\begin{array}{c}-0.151^{* *} \\
(0.068)\end{array}$ & & \\
\hline dur & & & & & & $\begin{array}{l}-0.000 \\
(0.000)\end{array}$ & \\
\hline catholic & & & & & & & $\begin{array}{c}0.189 \\
(0.138)\end{array}$ \\
\hline muslim & & & & & & & $\begin{array}{l}-0.077 \\
(0.129)\end{array}$ \\
\hline protestant & & & & & & & $\begin{array}{c}0.114 \\
(0.414)\end{array}$ \\
\hline Control variables $^{a}$ & yes & yes & yes & yes & yes & yes & yes \\
\hline Colony fixed effects & yes & yes & yes & yes & yes & yes & yes \\
\hline$N$ & 166 & 174 & 174 & 174 & 174 & 174 & 131 \\
\hline Log lik. & -62.78 & -68.74 & -67.50 & -69.11 & -66.95 & -68.99 & -46.22 \\
\hline Chi-squared & 56.86 & 43.10 & 44.32 & 44.28 & 39.17 & 43.78 & 34.79 \\
\hline
\end{tabular}

Robust standard errors in parentheses. ${ }^{*} p<0.10,{ }^{* *} p<0.05,{ }^{* * *} p<0.01$

${ }^{a}$ Incorporates intense, internal, interstate, lnpop, lngdp, lnopen, africa, asia, and europe. 


\section{Appendix}

Table A.1: Conflicts since 1945. IV stands for UN military intervention.

\begin{tabular}{|c|c|c|c|c|c|c|c|c|}
\hline Country & Year & IV & Country & Year & IV & Country & Year & IV \\
\hline \multicolumn{9}{|c|}{ Africa } \\
\hline Egypt & 1951 & yes & Tanzania & 1978 & & Centra Afr. Rep. & 2001 & yes \\
\hline Egypt & 1956 & yes & South Africa & 1978 & & Cote d'Ivoire & 2002 & yes \\
\hline Cameroon & 1960 & & Tunisia & 1980 & & Nigeria & 2003 & \\
\hline Ethiopia & 1960 & & Liberia & 1980 & yes & Nigeria & 2004 & \\
\hline Congo (DR) & 1960 & & Gambia & 1981 & & Djibouti & 2008 & \\
\hline Congo (DR) & 1960 & yes & Egypt & 1981 & & Mauritania & 2008 & \\
\hline Ethiopia & 1961 & yes & Kenya & 1982 & & Libya (NA) & 2011 & yes \\
\hline Algeria & 1963 & & Somalia & 1982 & yes & (Sudan) & 2011 & yes \\
\hline Sudan (NA) & 1963 & & Ethiopia & 1982 & & (Sudan) & 2011 & \\
\hline Congo (DR) & 1964 & yes & Chad & 1983 & & South Sudan (NA) & 2012 & yes \\
\hline Ethiopia & 1964 & & Burkina Faso & 1985 & & South Sudan (NA) & 2012 & \\
\hline Gabon & 1964 & & Togo & 1986 & & Mali (NA) & 2012 & \\
\hline Ethiopia & 1964 & & Burkina Faso & 1987 & & & & \\
\hline Burundi & 1965 & yes & Chad & 1987 & & Asia & & \\
\hline Ghana & 1966 & & Senegal & 1988 & & China (NA) & 1950 & \\
\hline Chad & 1966 & yes & Comoros & 1989 & & Indonesia (NA) & 1950 & \\
\hline Zimbabwe & 1966 & & Rwanda & 1990 & yes & Thailand & 1951 & \\
\hline South Africa & 1966 & yes & Mali & 1990 & & Indonesia (NA) & 1953 & \\
\hline Nigeria & 1966 & & Algeria & 1990 & & India & 1955 & \\
\hline Egypt & 1967 & yes & Sierra Leone & 1991 & yes & Vietnam (NA) & 1955 & \\
\hline Nigeria & 1967 & & Djibouti & 1991 & & Oman (NA) & 1957 & \\
\hline Cambodia (NA) & 1967 & yes & Angola & 1991 & yes & Malaysia & 1957 & \\
\hline Sudan & 1971 & yes & Ethiopia & 1991 & & Myanmar (NA) & 1957 & \\
\hline Morocco & 1971 & & Niger & 1991 & & $\operatorname{Iraq}(\mathrm{NA})$ & 1958 & yes \\
\hline Madagascar & 1971 & & Congo, Rep. & 1993 & & Lebanon (NA) & 1958 & yes \\
\hline Uganda & 1971 & & Eritrea & 1993 & & China & 1959 & \\
\hline Ethiopia & 1974 & & Niger & 1994 & & Myanmar (NA) & 1959 & \\
\hline Cambodia & 1975 & & Cameroon & 1994 & & Lao PDR (NA) & 1959 & \\
\hline Morocco & 1975 & yes & Niger & 1995 & & Nepal & 1960 & yes \\
\hline Angola & 1975 & yes & Comoros & 1997 & & Iraq (NA) & 1961 & \\
\hline Cambodia & 1975 & & Lesotho & 1998 & & Indonesia & 1962 & \\
\hline Ethiopia & 1975 & & Guinea-Bissau & 1998 & yes & Indonesia & 1962 & yes \\
\hline Mauritania & 1975 & & Eritrea & 1998 & yes & Malaysia & 1963 & \\
\hline Ethiopia & 1977 & & Congo (DR) & 1998 & yes & Thailand & 1965 & \\
\hline Mozambique & 1977 & yes & Guinea & 2000 & & Vietnam (NA) & 1965 & \\
\hline
\end{tabular}

Source: Uppsala Conflict Data Program (UCDP), using conflicts since 1950.

Exculding extrasystemic armed conflicts.

$\mathrm{NA}=$ data not available and conflict not included in sample.

Conflicts in parentheses use data from the World Bank for lngdp and lnopen. 
Table A.1 cont.: Conflicts since 1945. IV stands for UN military intervention.

\begin{tabular}{|c|c|c|c|c|c|c|c|c|}
\hline Country & Year & IV & Country & Year & IV & Country & Year & IV \\
\hline \multicolumn{2}{|l|}{ Asia } & & Pakistan & 1990 & & Bosnia \& Herz. & 1993 & \\
\hline Indonesia & 1965 & & Iraq & 1990 & yes & (Azerbaijan) & 1993 & \\
\hline India & 1966 & & Russia & 1990 & & Serbia & 1996 & yes \\
\hline Syria & 1966 & & (Tajikistan) & 1992 & yes & Macedonia, FYR & 2000 & \\
\hline Israel & 1967 & & (Tajikistan) & 1992 & & & & \\
\hline Israel & 1967 & yes & India & 1993 & & \multicolumn{2}{|c|}{ North America } & \\
\hline Oman (NA) & 1968 & & Russia & 1993 & & Cuba (NA) & 1953 & \\
\hline China & 1969 & & Yemen, Rep. & 1994 & & Honduras & 1957 & \\
\hline China & 1969 & & Russia & 1994 & & Dominican Rep. & 1965 & yes \\
\hline Philippines & 1970 & & Myanmar (NA) & 1997 & & El Salvador & 1969 & \\
\hline Pakistan & 1971 & & Russia & 1999 & & El Salvador & 1972 & yes \\
\hline Sri Lanka & 1971 & & Uzbekistan & 1999 & & Nicaragua & 1974 & yes \\
\hline Iran & 1972 & & Iraq & 2003 & & Grenada & 1983 & \\
\hline Iran & 1972 & & India & 2004 & & Panama & 1989 & \\
\hline Myanmar (NA) & 1973 & & India & 2005 & & Panama & 1989 & \\
\hline Pakistan & 1973 & & Russia & 2007 & & Haiti & 1989 & yes \\
\hline China & 1974 & & Myanmar (NA) & 2009 & & Trinidad \& Tobago & 1990 & \\
\hline Indonesia & 1975 & yes & & & & Mexico & 1994 & \\
\hline Bangladesh & 1975 & & \multicolumn{2}{|c|}{ Europe } & & United States & 2001 & \\
\hline Sri Lanka & 1975 & & Hungary (NA) & 1956 & & & & \\
\hline Afghanistan & 1978 & yes & France & 1961 & & \multicolumn{2}{|c|}{ South America } & \\
\hline Saudi Arabia (NA) & 1979 & & France & 1961 & & Argentina & 1955 & \\
\hline India & 1979 & & Spain & 1968 & & Venezuela & 1962 & \\
\hline Iran & 1979 & & United Kingdom & 1970 & & Colombia & 1964 & \\
\hline Afghanistan & 1979 & & Cyprus & 1974 & & Peru & 1965 & \\
\hline India & 1979 & & Romania & 1989 & & El Salvador & 1969 & \\
\hline India & 1981 & & (Georgia) & 1991 & & Uruguay & 1970 & \\
\hline Lao PDR & 1982 & & Serbia & 1991 & yes & El Salvador & 1972 & yes \\
\hline India & 1983 & & (Georgia) & 1991 & & Chile & 1973 & \\
\hline Turkey & 1983 & & Azerbaijan & 1991 & & Nicaragua & 1974 & yes \\
\hline India & 1984 & & (Moldova) & 1991 & & Argentina & 1982 & \\
\hline Israel & 1986 & & Serbia & 1991 & & Suriname & 1986 & \\
\hline Turkey & 1987 & & (Georgia) & 1992 & yes & Ecuador & 1995 & \\
\hline Indonesia & 1989 & & Bosnia \& Herz. & 1992 & & & & \\
\hline India & 1989 & & Croatia & 1992 & yes & \multicolumn{2}{|c|}{ Oceania } & \\
\hline Russia & 1990 & & Bosnia \& Herz. & 1992 & yes & Papua New G. & 1989 & \\
\hline
\end{tabular}

Source: Uppsala Conflict Data Program (UCDP), using conflicts since 1950.

Exculding extrasystemic armed conflicts.

$\mathrm{NA}=$ data not available and conflict not included in sample.

Conflicts in parentheses use data from the World Bank for lngdp and lnopen. 
Table A.2: Summary statistics

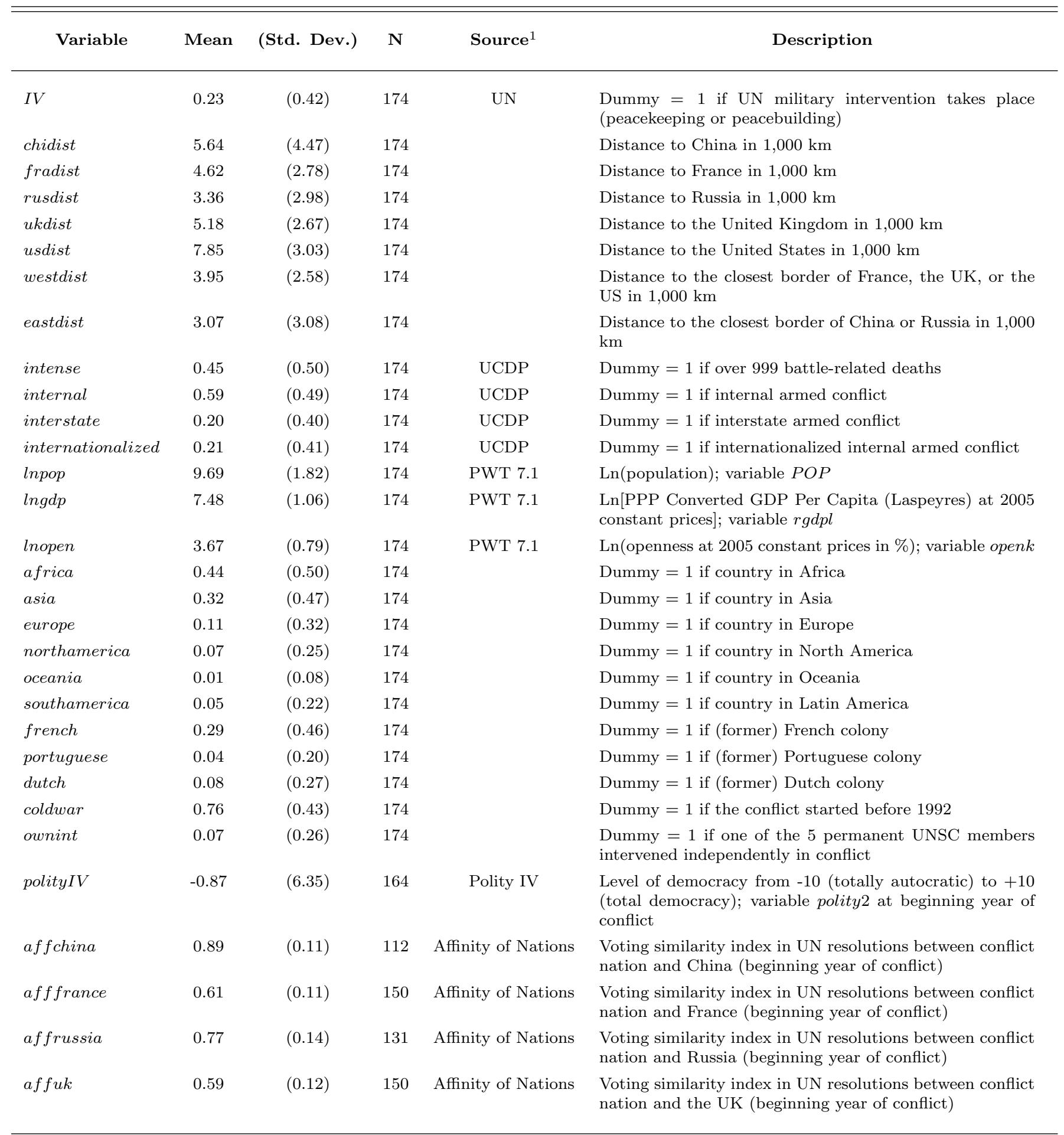

\footnotetext{
${ }^{1} \mathrm{UN}=\mathrm{UN}$ Security Council resolutions; UCDP = Uppsala Conflict Data Program; PWT = Penn World Table version 7.1.
} 
Table A.2 cont.: Summary statistics

\begin{tabular}{|c|c|c|c|c|c|}
\hline Variable & Mean & (Std. Dev.) & $\mathbf{N}$ & Source $^{1}$ & Description \\
\hline affus & 0.44 & $(0.20)$ & 149 & Affinity of Nations & $\begin{array}{l}\text { Voting similarity index in UN resolutions between con- } \\
\text { flict nation and the US (beginning year of conflict) }\end{array}$ \\
\hline affwest & 0.63 & $(0.10)$ & 150 & Affinity of Nations & $\begin{array}{l}\text { Voting similarity index in UN resolutions between con- } \\
\text { flict nation and the maximum score from France, the } \\
\text { UK, or the US (beginning year of conflict) }\end{array}$ \\
\hline affeast & 0.84 & $(0.15)$ & 144 & Affinity of Nations & $\begin{array}{l}\text { Voting similarity index in UN resolutions between con- } \\
\text { flict nation and the maximum score from China or } \\
\text { Russia (beginning year of conflict) }\end{array}$ \\
\hline lnexportstous & 0.83 & $(2.59)$ & 158 & Correlates of War & $\begin{array}{l}\text { Ln(total exports of conflict country to the US at be- } \\
\text { ginning year of conflict) }\end{array}$ \\
\hline lnimportsfromus & 0.96 & $(2.23)$ & 158 & Correlates of War & $\begin{array}{l}\text { Ln(total imports of conflict country from the US at } \\
\text { beginning year of conflict) }\end{array}$ \\
\hline lnexportstowest & 1.80 & $(2.23)$ & 154 & Correlates of War & $\begin{array}{l}\mathrm{Ln} \text { (total exports of conflict country to France, the UK, } \\
\text { and the US at beginning year of conflict) }\end{array}$ \\
\hline lnimportsfromwest & 1.91 & $(1.84)$ & 154 & Correlates of War & $\begin{array}{l}\text { Ln(total imports of conflict country from France, the } \\
\text { UK, and the US at beginning year of conflict) }\end{array}$ \\
\hline lntotalaid & 18.13 & $(1.93)$ & 145 & World Bank & $\begin{array}{l}\mathrm{Ln} \text { (total aid received by conflict country at beginning } \\
\text { year of conflict) }\end{array}$ \\
\hline lnaidus & 16.83 & $(1.73)$ & 118 & World Bank & $\begin{array}{l}\mathrm{Ln} \text { (total aid received by conflict country from the US } \\
\text { at beginning year of conflict) }\end{array}$ \\
\hline saudidist & 3.32 & $(3.37)$ & 174 & & Distance to Saudi Arabia in $1,000 \mathrm{~km}$ \\
\hline iraqdist & 3.83 & $(3.38)$ & 174 & & Distance to Iraq in $1,000 \mathrm{~km}$ \\
\hline irandist & 3.68 & $(3.50)$ & 174 & & Distance to Iran in $1,000 \mathrm{~km}$ \\
\hline kuwaitdist & 4.22 & $(3.47)$ & 174 & & Distance to Kuwait in $1,000 \mathrm{~km}$ \\
\hline venezueladist & 9.01 & $(4.25)$ & 174 & & Distance to Venezuela in $1,000 \mathrm{~km}$ \\
\hline isrdist & 3.98 & $(3.31)$ & 174 & & Distance to Israel in $1,000 \mathrm{~km}$ \\
\hline $\operatorname{cinc}$ & 0.01 & $(0.03)$ & 166 & Correlates of War & Composite Index of National Capability score \\
\hline year & 1980.66 & $(14.08)$ & 174 & UCDP & Beginning year of conflict \\
\hline currentivs & 6.51 & $(5.64)$ & 174 & UN & $\begin{array}{l}\text { Amount of ongoing military UN interventions at the } \\
\text { beginning year of the conflict }\end{array}$ \\
\hline ivprev & 0.07 & $(0.25)$ & 174 & $\mathrm{UN}$ & Dummy $=1$ if UN intervened in country before \\
\hline unmember & 0.95 & $(0.22)$ & 174 & $\mathrm{UN}$ & $\begin{array}{l}\text { Dummy }=1 \text { if conflict country is UN member in the } \\
\text { beginning year of the conflict }\end{array}$ \\
\hline member & 0.28 & $(0.45)$ & 174 & UN & $\begin{array}{l}\text { Dummy }=1 \text { if conflict country was a non-permanent } \\
\text { member of the UNSC at any time during the conflict }\end{array}$ \\
\hline$d u r$ & 143.02 & $(170.26)$ & 174 & UCDP & Duration of conflict in months (until December 2012) \\
\hline catholic & 23.58 & $(32.83)$ & 131 & QoG & Percentage catholic in society in 1980 \\
\hline muslim & 32.59 & $(36.73)$ & 131 & QoG & Percentage muslim in society in 1980 \\
\hline protestant & 6.23 & $(10.77)$ & 131 & QoG & Percentage protestant in society in 1980 \\
\hline
\end{tabular}

${ }^{1} \mathrm{UCDP}=$ Uppsala Conflict Data Program; QoG = Quality of Government index from Teorell et al. (2011). 


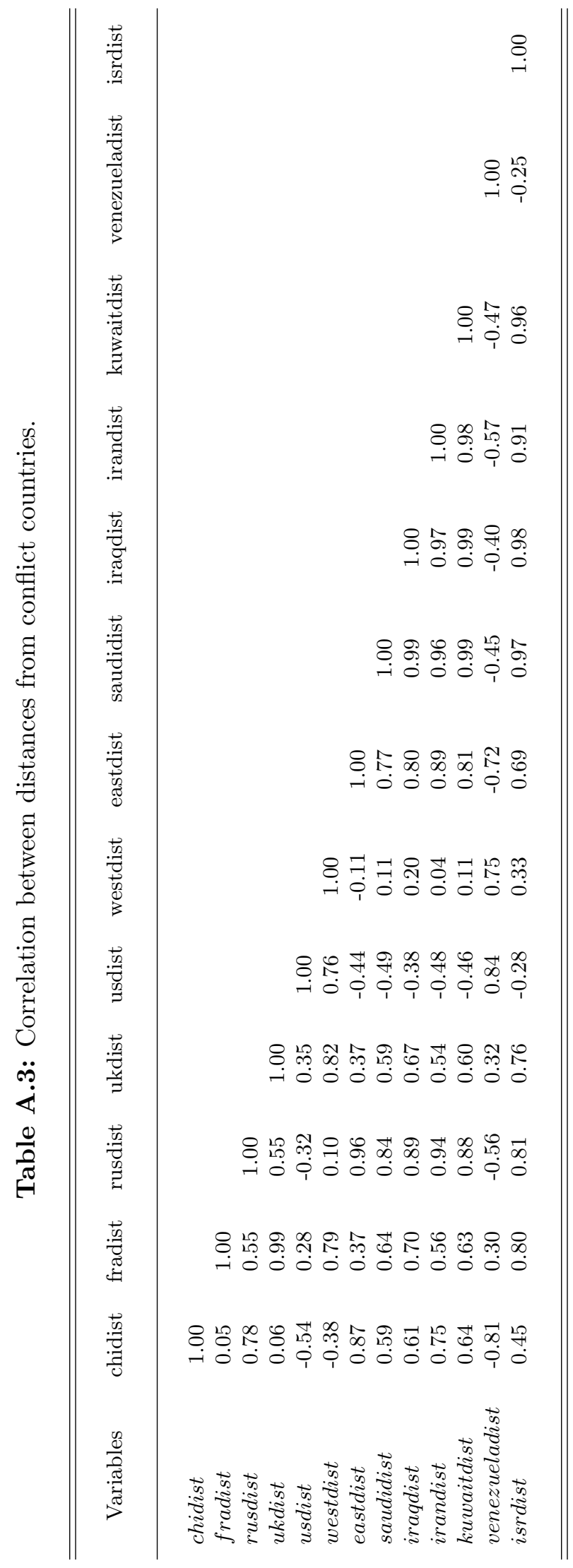

